\title{
Wildlife-pet markets in a one-health context
}

\author{
Clifford Warwick (i) and Catrina Steedman (D) \\ Emergent Disease Foundation, Kent, UK. \\ Corresponding author: Clifford Warwick, e-mail: cliffordwarwick@gmail.com \\ Co-author: CS: catrinasteedman@gmail.com \\ Received: 23-10-2020, Accepted: 01-02-2021, Published online: 06-03-2021
}

doi: www.doi.org/10.14202/IJOH.2021.42-64 How to cite this article: Warwick C, Steedman C (2021) Wildlife-pet markets in a one-health context, Int. J. One Health, 7(1): 42-64.

\begin{abstract}
Background and Aim: Wildlife markets are centers of trade involving live animals and their derivatives from wild-caught and captive-bred non-domesticated animals, including for the culinary, fashion, traditional medicine, curio, and pet sectors. These markets occur in Southeast Asia, India, North America, Latin America, Europe, Africa, and elsewhere. This study aims to address a diversity of related issues that have a one-health bearing while focusing on wildlife markets in relation to the pet trade. Across relevant regions and countries, all major animal classes are traded at wildlife-pet markets. Wildlife markets, in general, are considered distinct from so-called "wet markets" at which domesticated animals, fish, and other "seafood" are offered only for consumption. Several aspects of wildlife markets have attracted scientific and popular scrutiny, including animal welfare concerns, species conservation threats, legality, ecological alteration, introduction of invasive alien species, presence of undescribed species, and public and agricultural animal health issues.
\end{abstract}

Materials and Methods: Onsite inspections were conducted for markets in the United States, Spain, Germany, The Netherlands, and the UK, as well as observational research of visual imagery of market conditions, and we compared these conditions with evidence-based standards for animal welfare and public health management.

Results: Wildlife markets globally shared common similar structures and practices including the presence of sick, injured, or stressed animals; mixing of animals of uncertain origin and health state; and no specific or any hygiene protocols, with issues of animal welfare, public health and safety, agricultural animal health, and other one-health concerns being inherently involved.

Conclusion: We conclude that wildlife markets are incompatible with responsible standards and practices, and we recommend that such events are banned globally to ameliorate inherent major problems.

Keywords: animal welfare, disease, exotic pet, one-health, pathogen, public health, wildlife market, zoonoses.

\section{Introduction}

Wildlife markets are centers of trade involving live animals and their derivatives from wild-caught and captive-bred non-domesticated animals, including for the culinary, fashion, traditional medicine, curio, and pet sectors [1-8]. These markets occur in Southeast Asia, India, North America, Latin America, Europe, Africa, and elsewhere. Definitions of "wild" and "non-domesticated" animals vary, although for this study we have adopted the position that these refer to species other than traditional domesticated forms such as household dogs and cats. The character of wildlife markets and the types of species displayed and sold are highly variable, and the fate of animals differs according to the intention of the purchaser; thus trading entities may be regarded as multi-purpose sellers. Across relevant regions and countries, all major animal classes (invertebrates, fishes, amphibians, reptiles, birds, and mammals) are traded at wildlife markets [1-4,6-37]. Wildlife markets are considered

Copyright: Warwick and Steedman. This article is an open access article distributed under the terms of the Creative Commons Attribution 4.0 International License (http://creativecommons.org/ licenses/ by/4.0/), which permits unrestricted use, distribution, and reproduction in any medium, provided you give appropriate credit to the original author(s) and the source, provide a link to the Creative Commons license, and indicate if changes were made. The Creative Commons Public Domain Dedication waiver (http:// creativecommons.org/ publicdomain/zero/1.0/) applies to the data made available in this article, unless otherwise stated. distinct from so-called "wet markets" at which domesticated animals, fish, and other "seafood" are offered only for consumption, even though some of these animals (fish and other seafood) are also effectively "wildlife." Wildlife markets include both static centers in which animals are displayed and sold through semi-permanent or permanent stalls and floorspaces, as well as itinerant events for which animals are transported regionally or across international borders to be displayed and sold at periodic venues $[1,2,4,38]$.

Several aspects of wildlife markets have attracted scientific and popular scrutiny and criticism, including their association with use of large numbers of individual animals, species conservation threats arising from uncontrolled or poorly monitored and regulated trade, legality, ecological alteration due to removal of large numbers of animals from indigenous habitats, introduction of invasive alien species, presence of undescribed species, and in particular, animal welfare due to abusive handling and husbandry practices, and public and agricultural animal health due to the presence of diverse pathogens and epidemiologic outbreaks and pandemics $[2,4,5,34,35,39,40]$. All these issues are relevant to this report, although in particular, we will focus on animal welfare and public health implications of wildlife markets in relation to the pet trade. Wildlife-pet markets involve diverse yet often interrelated issues that collectively assume one-health 
importance; thus the present study includes various subjects with impacts relevant to these events.

Wildlife-pet markets are a global phenomenon that attracts multifactorial concerns. Accordingly, this study is significant because it investigates both the interrelatedness of these concerns as well as their implications across animal, human, and environmental health domains.

This study aims to address a diversity of related issues that have a one-health bearing while focusing on wildlife markets in relation to the pet trade. In particular, implications of wildlife-pet markets in relation to animal, human, and environmental health are examined, and recommendations are offered to remedy ongoing concerns.

\section{Materials and Methods}

\section{Ethical approval}

Ethical approval is not need for this study.

\section{Databases search criteria}

A literature search was conducted using online engines Google, Google Scholar, and PubMed databases, including the following key terms individually: "Wildlife markets," "exotic pet market," "live animal market," "wildlife markets"/“exotic pet market"/"live animal market"/+ "zoonoses," "pathogen," "virus," "bacteria," "infection," "disease," "pet fair," "invertebrate expo," "invertebrate show," "koi fish fair," "koi fish expo," "koi fish show," "amphibian fair," "amphibian expo," "amphibian show," "reptile fair," "reptile expo," "reptile show," "bird expo," "bird fair," "bird show," "mammal fair," "mammal expo," and "mammal show."

\section{Inclusion and exclusion criteria}

The search returned 143 results, which included both scientific and semi-scientific reports, of which 38 were directly relevant to wildlife markets after exclusion of references dealing exclusively with domesticated animals and traditional wet market venues. Several journalistic articles were also included due to their value as visual resources for identifying which classes of animals were on sale at certain venues. On-file library database resources were also used in respect of zoonoses and public health information.

\section{Categorization of wildlife markets}

Categorization of wildlife markets by region or country and character mined by onsite inspections of wildlife-pet markets in the US, Spain, Germany, The Netherlands, and UK, from descriptions within published reports, and from visual assessment of imagery within published reports. Comparison of similarities and differences in husbandry and animal welfare, hygiene, and public access at wildlife markets by region or country (Table-2) $[2-4,6,7,12,15,18,26,27,29-32,34-36,43-49]$ was based on onsite observations at markets in the US, Spain, Germany, The Netherlands, and UK, and of publicly available (photographic and film) images pertaining to wildlife markets for all relevant regions and countries. Evaluations of standards were based on scientific guidelines for global pet animal husbandry in commercial establishments [43] (Table-2). Reported minimum number and class of potential human pathogens associated with wild-pet animals (Table-3) [26,27,44,45,5059], and for example, wildlife-associated infections and zoonotic epidemics or pandemics (Table-4) [6089], were developed from the search-based published literature results. We also circulated drafts of Tables-1 and 2 to eight authors of published scientific investigations into wildlife markets to obtain experiential comments and/or verification. Seven responses were received, all of which provided valuable insight and information that was subsequently added to the tables.

\section{Results and Discussion}

\section{Character and distribution of wildlife-pet markets}

Southeast Asian wildlife markets and related cultural wildlife markets in other regions, such as "Chinatowns" in North America, and Europe, commonly share similar structures and practices such as: Disorderly and arbitrary husbandry and display of animals; presence of diseased, injured, or stressed animals; mixing of animals of uncertain origin and condition; and no specific or any hygiene protocols [30-32]. North American and European wildlife markets typically present as more orderly and many include specific hygiene protocols, such as recommendations for hand-washing and provision of antimicrobial cleansers [2]. However, issues such as the presence of sick, injured, or stressed animals; mixing of animals of uncertain origin and health state; and no specific or any hygiene protocols also remain common to Western (occurring in the western global hemisphere) wildlife-pet markets. Thus, whereas husbandry standards may appear better (or less poor) and involve a greater degree of operational hygiene at Western-pet wildlife markets than at Latin American, Southeast Asian, Indian, and African markets, problematic issues differ by degree but remain implied. Table-1 provides examples of wildlife-pet markets by region or country, and character.

\section{Animal welfare}

Animal welfare is a globally recognized evidence-based scientific discipline. Despite profound morphological, behavioral and other characteristic differences between species and classes, issues of variation regarding sentience (e.g., pain perception, emotions, consciousness, stress, and other factors) appear similarly common to both human and non-human animal biology, including among studied invertebrates, fishes, amphibians, reptiles, birds, and mammals [90-116].

Relatedly, these and many other reports confirm that, for example, habitat variation, species-relevant spatial ranges and requirements, expression of normal behaviors, sociality, control over environment, and preference selection are biological needs associated with positive physiological, psychological, and 
Table-1: Example wildlife-pet markets by region or country, and character.

\begin{tabular}{|c|c|c|c|}
\hline Region or country & Animals by class & $\begin{array}{l}\text { Common character } \\
\text { of events }\end{array}$ & Sample references \\
\hline \multicolumn{4}{|l|}{ Southeast Asia } \\
\hline $\begin{array}{l}\text { For example, China, Cambodia, } \\
\text { Japan, Thailand, Vietnam, } \\
\text { Philippines, Indonesia }\end{array}$ & $\begin{array}{l}\text { Invertebrates, fishes, } \\
\text { amphibians, reptiles, birds, } \\
\text { mammals }\end{array}$ & $\begin{array}{l}\text { Static centers/ } \\
\text { itinerant events }\end{array}$ & $\begin{array}{l}{[1,3,4,6,8,11,15,17} \\
28,29,33,41]\end{array}$ \\
\hline \multicolumn{4}{|l|}{$\begin{array}{l}\text { Cultural (e.g., Toronto, San } \\
\text { Francisco, New York, European } \\
\text { "Chinatowns") }\end{array}$} \\
\hline $\begin{array}{l}\text { For example, Canada (Toronto), USA } \\
\text { (San Francisco, New York, Illinois) } \\
\text { "Chinatowns" }\end{array}$ & $\begin{array}{l}\text { Invertebrates, fishes, } \\
\text { amphibians, reptiles, } \\
\text { birds, mammals }\end{array}$ & Static centers & {$[12,30-32]$} \\
\hline \multicolumn{4}{|l|}{ North America } \\
\hline Canada & $\begin{array}{l}\text { Invertebrates, fishes, } \\
\text { amphibians, reptiles, birds, } \\
\text { mammals }\end{array}$ & Itinerant events & {$[22,24,25,36,42]$} \\
\hline USA & $\begin{array}{l}\text { Invertebrates, fishes, } \\
\text { amphibians, reptiles, birds, } \\
\text { mammals }\end{array}$ & Itinerant events & {$[19,20,23,26,27]$} \\
\hline \multicolumn{4}{|l|}{ Europe } \\
\hline $\begin{array}{l}\text { For example, United Kingdom, } \\
\text { Germany, Czech Republic, The } \\
\text { Netherlands, Spain }\end{array}$ & $\begin{array}{l}\text { Invertebrates, fishes, } \\
\text { amphibians, reptiles, birds, } \\
\text { mammals }\end{array}$ & Itinerant events & {$[2,21,26,27,34,35]$} \\
\hline \multicolumn{4}{|l|}{ Latin America } \\
\hline $\begin{array}{l}\text { For example, Bolivia, El Salvador, } \\
\text { Mexico, Peru }\end{array}$ & $\begin{array}{l}\text { Invertebrates, fishes, } \\
\text { amphibians, reptiles, birds, } \\
\text { mammals }\end{array}$ & Static centers & {$[13,14,37]$} \\
\hline \multicolumn{4}{|l|}{ Africa } \\
\hline $\begin{array}{l}\text { For example, Congo, Mali, Nigeria, } \\
\text { Togo }\end{array}$ & $\begin{array}{l}\text { Invertebrates, fishes, } \\
\text { amphibians, reptiles, birds, } \\
\text { mammals }\end{array}$ & Static centers & {$[7,9,10,13,16,18,26]$} \\
\hline
\end{tabular}

Static centers=Animals displayed and sold through semi-permanent or permanent stalls and floor spaces. Itinerant events=Animals transported regionally or across international borders to be displayed and sold at periodic venues

behavioral health states and good welfare. Conversely, deprivations of any or all of these biological needs are implicit in multifactorially poor health and welfare. Furthermore, factors such as capture, handling; transportation; confinement; inappropriate temperatures and thermal gradients; inappropriate humidity and light; noise and vibration disturbance; inappropriate diets; and inappropriate or deficient enrichment, constitute additional imposed stressors associated with negative physiological, psychological, and behavioral health states and poor welfare $[43,90-114,117,118]$.

Commerce in animals as pets through wildlife markets raises several particular welfare issues. The following examples provide a relevant summary: Spatial provisions - minimum spatial standards determine that animals should be able to fully stretch, perform a range of normal behaviors, and exercise, and that all animals must be able to access any provision (such as drinking bowls, food bowls, bathing pools, basking sites, and shelters) at any one time [43]. Food and water provisions - nutritional materials and drinking fluids should be of balanced values where appropriate, stored, and prepared in suitably hygienic conditions, offered in suitable containers, and provided in adequate amounts and at regular frequencies [43]. Enrichment provisions - environmental enrichment should be present and reflect the relevant habitat and behavioral needs of animals [43]. Handling - animals should be handled considerately and in a "fear-free" manner [119]. Positioning of animals and cages enclosures should be rationally positioned, cage stacking (e.g., cage on cage) should be avoided due to risks of descending waste contamination, predator and prey species should not be kept proximally, and cages generally should not be positioned on floors or other vulnerable areas [43]. Welfare assessments - regular examinations should be conducted for signs of stress, injury, or disease [43].

However, wildlife-pet markets typically involve conditions that severely deprive animals of all the above-stated husbandry protocols and welfare needs $[2,7,26,27,34,35,44-47,77,120]$. Indeed, objective investigations of animal welfare at wildlife-pet markets appear to involve universally negative descriptions (Table-2). Conditions typically involve a series of stalls at which animals are highly restrictively confined and crowded together in various wire cages, glass vivaria, large bowls, trays, buckets, nets, wooden boxes, or plastic tubs that are frequently positioned on the ground or on floor areas, or stacked onto each other [15]. Hygiene is commonly poor, and cage-stacking allows animal waste to descend to lower enclosures, increasing contamination [15]. Positioning of wire cages on streets [15] or on table-tops [2,35] causes animals to be exposed to passers-by, and this potential stressor combined with a generalized lack of seclusion contributes to probable stress factors. Often animals are exposed to direct sunlight [15], 
Table-2: Similarities and differences in husbandry and animal welfare, hygiene, and public access between Southeast Asian, Indian, Cultural, Western (USA, Canada, Europe), Latin American, and African wildlife-pet markets.

Southeast Asian wildlife-pet markets (e.g., China, Cambodia, Thailand, Vietnam, the Philippines, and Indonesia)

\begin{tabular}{|c|c|c|c|c|}
\hline \multicolumn{2}{|c|}{ Husbandry and animal welfare } & $\begin{array}{l}\text { Hygiene } \\
\text { Poor }\end{array}$ & $\begin{array}{l}\text { Proximity to } \\
\text { public/access } \\
\text { Proximal and } \\
\text { direct contact }\end{array}$ & $\begin{array}{l}\text { Figures Sample references } \\
\begin{aligned} & 1,2,3,4 {[15,29,34,43] \text { and visual material } } \\
& \text { observations based on Warwick } \\
& \text { et al. }[43]\end{aligned}\end{array}$ \\
\hline $\begin{array}{l}\text { Criteria } \\
\text { Spatial provisions } \\
\text { Food and water provisions } \\
\text { Enrichment provisions } \\
\text { Handling frequency } \\
\text { Handling (considerate/ } \\
\text { abusive) } \\
\text { Number of proximal animals } \\
\text { Positioning of animals and } \\
\text { cages } \\
\text { (e.g., floor, table top, cage } \\
\text { on cage) } \\
\text { Proximity to other animals/ } \\
\text { species } \\
\text { Signs of stress, injury or } \\
\text { disease } \\
\text { Animal welfare concerns }\end{array}$ & $\begin{array}{l}\text { Determination } \\
\text { Overly restrictive/ } \\
\text { overcrowded/poor } \\
\text { None/poor } \\
\text { None } \\
\text { Common } \\
\text { Abusive/poor } \\
\text { High } \\
\text { Extremely poor } \\
\text { Direct/close } \\
\text { Common } \\
\text { High/extreme }\end{array}$ & Poor & $\begin{array}{l}\text { Proximal and } \\
\text { direct contact }\end{array}$ & $\begin{aligned} & 1,2,3,4 {[15,29,34,43] \text { and visual material } } \\
& \text { observations based on Warwick } \\
& \text { et al. }[43]\end{aligned}$ \\
\hline
\end{tabular}

\begin{tabular}{|c|c|c|c|c|}
\hline \multicolumn{5}{|c|}{ Cultural wildlife-pet markets (e.g., Toronto, San Francisco, New York "Chinatowns") } \\
\hline Husbandry and animal wel & lfare & Hygiene & $\begin{array}{l}\text { Proximity to } \\
\text { public/access }\end{array}$ & Sample references \\
\hline $\begin{array}{l}\text { Criteria } \\
\text { Spatial provisions } \\
\text { Food and water provisions } \\
\text { Enrichment provisions } \\
\text { Handling frequency } \\
\text { Handling (considerate/ } \\
\text { abusive) } \\
\text { Number of proximal animals } \\
\text { Positioning of animals and } \\
\text { cages } \\
\text { (e.g., floor, table top, cage } \\
\text { on cage) } \\
\text { Proximity to other animals/ } \\
\text { species } \\
\text { signs of stress, injury or } \\
\text { disease } \\
\text { Animal welfare concerns }\end{array}$ & $\begin{array}{l}\text { Determination } \\
\text { Overly restrictive/ } \\
\text { overcrowded/poor } \\
\text { None/infrequent/ } \\
\text { poor } \\
\text { None/poor } \\
\text { Common } \\
\text { Abusive/poor } \\
\text { High } \\
\text { Poor } \\
\text { Direct/close } \\
\text { Common } \\
\text { High/extreme }\end{array}$ & Poor & $\begin{array}{l}\text { Proximal and } \\
\text { direct contact }\end{array}$ & $\begin{array}{l}{[12,30-32] \text { and visual material }} \\
\text { observations based on Warwick } \\
\text { et al. [43] }\end{array}$ \\
\hline
\end{tabular}

\begin{tabular}{|c|c|c|c|c|}
\hline \multicolumn{5}{|c|}{ North American and European wildlife-pet markets (e.g., Canada, USA, and Europe) } \\
\hline Husbandry and animal we & elfare & Hygiene & $\begin{array}{l}\text { Proximity to } \\
\text { public/access }\end{array}$ & Figures Sample references \\
\hline $\begin{array}{l}\text { Criteria } \\
\text { Spatial provisions } \\
\text { Food and water provisions } \\
\text { Enrichment provisions } \\
\text { Handling frequency } \\
\text { Handling (considerate/ } \\
\text { abusive) } \\
\text { Number of proximal animals } \\
\text { Positioning of animals and } \\
\text { cages } \\
\text { (e.g., floor, table top, cage } \\
\text { on cage) } \\
\text { Proximity to other animals/ } \\
\text { species } \\
\text { Signs of stress, injury or } \\
\text { disease } \\
\text { Animal welfare concerns }\end{array}$ & $\begin{array}{l}\text { Determination } \\
\text { Overly restrictive/ } \\
\text { overcrowded/poor } \\
\text { None/infrequent/ } \\
\text { poor } \\
\text { None/infrequent/ } \\
\text { poor } \\
\text { Common } \\
\text { Poor/considerate } \\
\text { High } \\
\text { Poor } \\
\text { Direct/close } \\
\text { Common } \\
\text { High }\end{array}$ & $\begin{array}{l}\text { Variable: } \\
\text { Low/ } \\
\text { moderate }\end{array}$ & $\begin{array}{l}\text { Proximal and } \\
\text { direct contact }\end{array}$ & $\begin{array}{c}5,6,7,8,9[2,26,27,34-36,44-49] \text { and visual } \\
\text { material observations based on } \\
\text { Warwick et al. }[43]\end{array}$ \\
\hline
\end{tabular}


Table-2: (Continued).

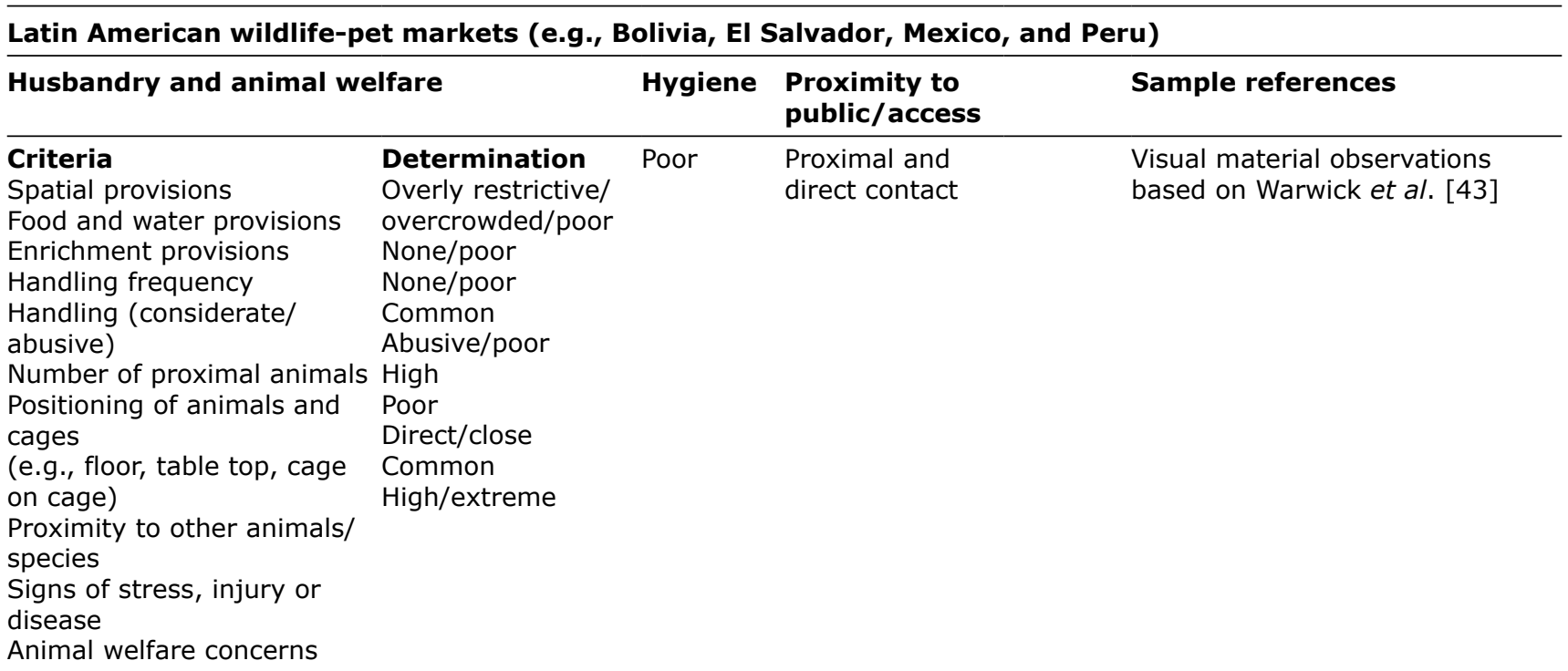

\begin{tabular}{|c|c|c|c|c|c|}
\hline \multicolumn{6}{|c|}{ African wildlife-pet markets (e.g., Congo, Mali, Nigeria, and Togo) } \\
\hline Husbandry and animal wel & Ifare & Hygiene & $\begin{array}{l}\text { Proximity to } \\
\text { public/access }\end{array}$ & Figures & Sample references \\
\hline $\begin{array}{l}\text { Criteria } \\
\text { Spatial provisions } \\
\text { Food and water provisions } \\
\text { Enrichment provisions } \\
\text { Handling frequency } \\
\text { Handling (considerate/ } \\
\text { abusive) } \\
\text { Number of proximal animals } \\
\text { Positioning of animals and } \\
\text { cages } \\
\text { (e.g., floor, table top, cage } \\
\text { on cage) } \\
\text { Proximity to other animals/ } \\
\text { species } \\
\text { Signs of stress, injury or } \\
\text { disease } \\
\text { Animal welfare concerns }\end{array}$ & $\begin{array}{l}\text { Determination } \\
\text { Overly restrictive/ } \\
\text { overcrowded/poor } \\
\text { None/poor } \\
\text { None/poor } \\
\text { Common } \\
\text { Abusive/poor } \\
\text { High } \\
\text { Poor } \\
\text { Direct/close } \\
\text { Common } \\
\text { High/extreme }\end{array}$ & Poor & $\begin{array}{l}\text { Proximal and } \\
\text { direct contact }\end{array}$ & 10 & $\begin{array}{l}{[7,27] \text { and visual material }} \\
\text { observations based on Warwick } \\
\text { et al. }[43]\end{array}$ \\
\hline
\end{tabular}

Resources for imagery analysis: $[2-4,6,7,15,18,27,29-32,35]$

increasing potential for heat stress. Predator and prey species are frequently held in close visual and olfactory proximity $[15,35]$, which presents additional possible causes of stress. Food and water provision is subject to stall-holder habits and may be regularly, occasionally, rarely or never provided $[2,15,35]$, and husbandry in general is poor $[2,7,15,27,35]$. Frequent inconsiderate and abusive handling are also a major concern [2,7,15,27,35,121]. Meta-issues regarding stress are also commonly reported as associated with "behind scenes" capture, transportation, and storage - with some animals being held captive or displayed for days or weeks $[2,7,15,18,26,27,35]$. Observations of stress-related behavior, morbidity, and injury are also often reported [2,7,15,27,35], indicating frequent poor physiological, psychological, and behavioral condition.

Animals used for their derivatives are commonly subject to live-boiling [29-32,121-123], live evisceration and dismemberment [29-32,124], and live decapitation [7,29-32,125]. Live-boiling of any animal across all classes can be considered inhumane [126-129]. Live-evisceration of any animal across all classes can be considered inhumane, and live-decapitation of fishes, amphibians, and reptiles has been shown to involve long periods (commonly $30 \mathrm{~min}$ to over $1 \mathrm{~h}$ ) of post-severance consciousness, and thus exposure to pain and stress, due to inherent resistance of neurological tissue to hypoxia, a feature also probably relevant to invertebrates [126-130]. Therefore, none of the commonly used methods for killing animals at wildlife markets can be considered humane or acceptable.

Accordingly, husbandry practices and treatment of animals in a welfare context at wildlife markets can probably be objectively regarded as inherently inconsiderate to extreme abuse. The following figures provide examples of wildlife-pet markets globally: Figures-1-4 Southeast Asia (Indonesia); Figure-5 North America (United States); Figures-6-9 Europe 


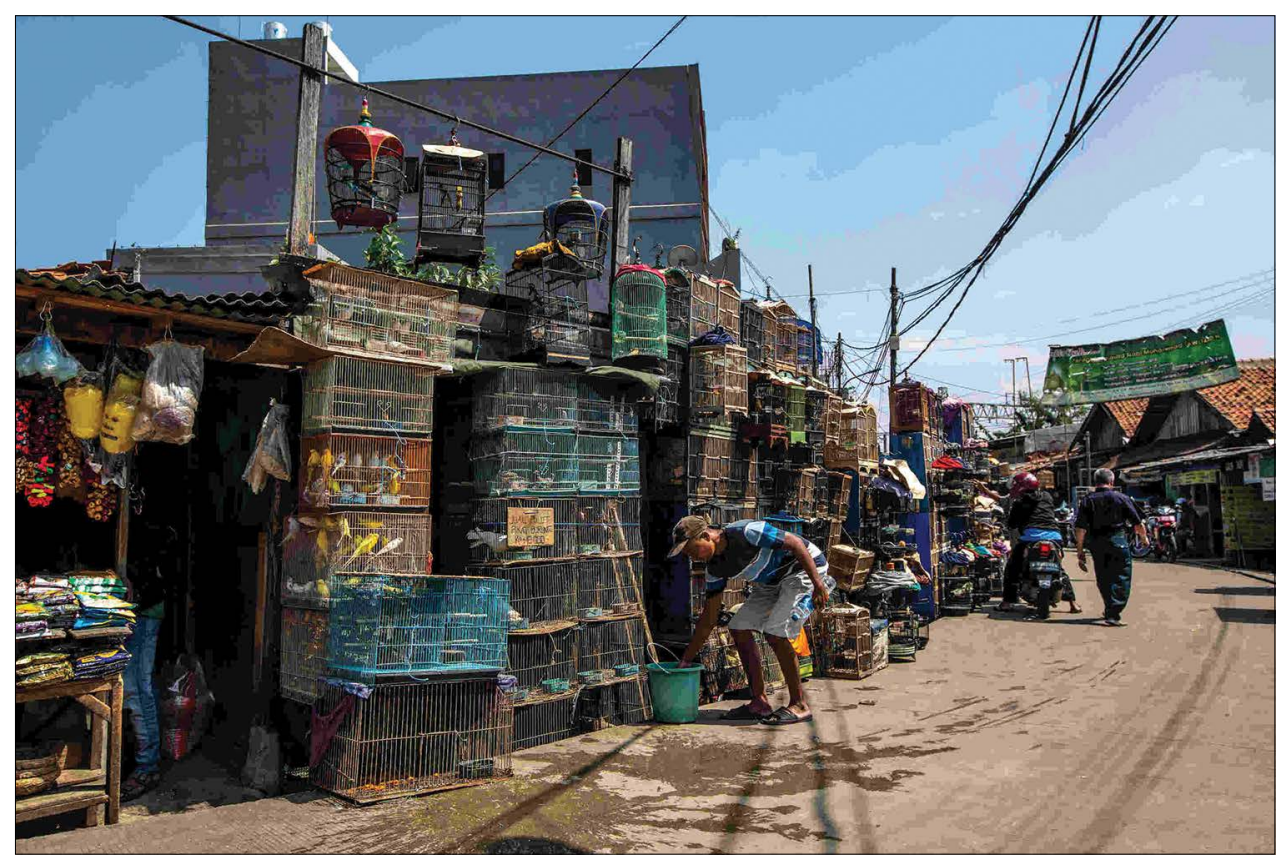

Figure-1: Wildlife market (birds and mammals), Jatinegara, Jakarta. (Credit: Aaron Gekoski, World Animal Protection).

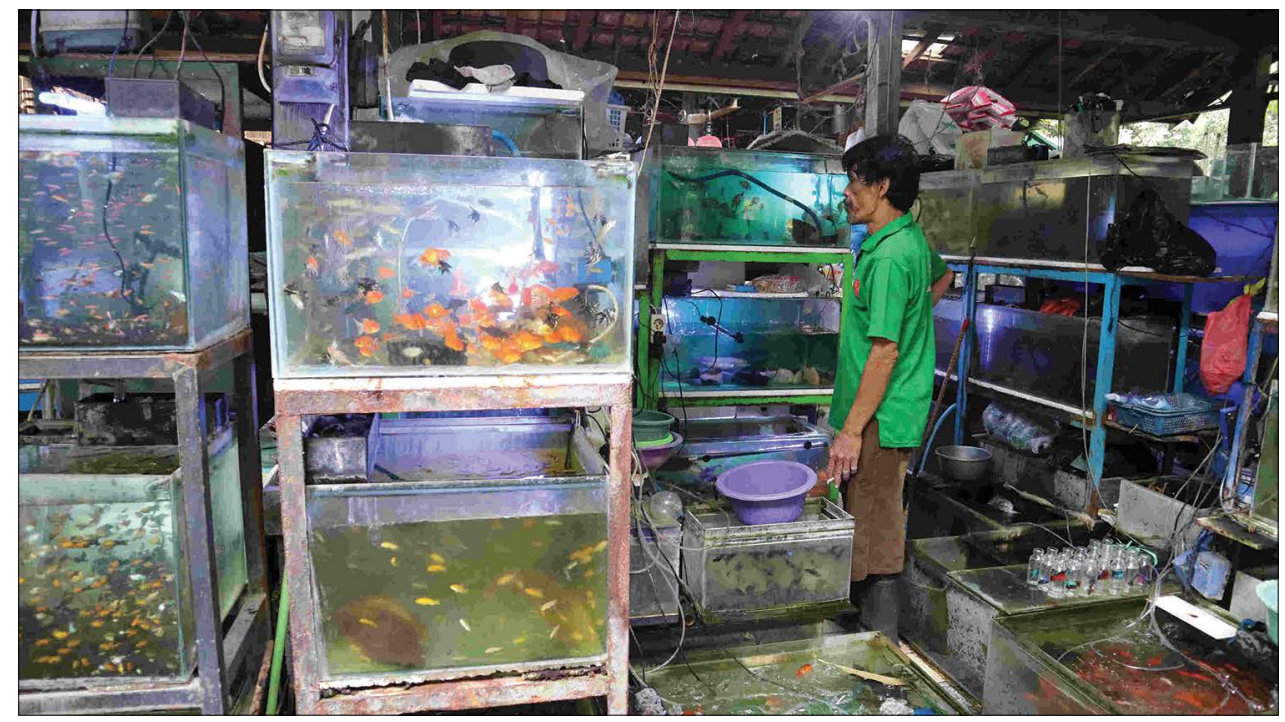

Figure-2: Wildlife market (fishes), Yogyakarta, Indonesia. (Credit: Satya Putra Shutterstock).

(United Kingdom and Germany); and Figure-10 Africa (Egypt).

\section{Public health}

Wildlife-associated human infections and infestations involve both strictly zoonotic diseases in which infections or infestations from diseased individuals are passed in either direction between animals and people (trans-species diseases) [131,132], such as rabies [133], and animal-associated human infections or infestations in which commensal or opportunistic microbes are passed from unaffected animals to people (trans-species pathogens) [44], such as reptile-associated salmonellosis [134]. Over 200 animal-associated human infections, infestations, and zoonoses are known [135], of which at least 70 are associated with exotic pets [44]. Wildlife-associated pathogens constitute significant sources of disease in humans.
For example, $75 \%$ of global emerging human infections are linked to wildlife [131], and of more than 1400 surveyed human diseases, $61 \%$ were found to be of potentially zoonotic origin [11]. Animal-associated human infections and infestations involve all classes of pathogenic agent (viral, bacterial, mycotic, microparasitic, macroparasitic, and prion) [44]. While much is known regarding epidemiology and management for some diseases and pathogens (e.g., reptile-associated salmonellosis [Salmonella spp.] and rabies [Rhabdovirus spp.]), comprehensive data regarding incidence and prevalence for most zoonotic and related issues are lacking $[40,50,132,136]$. In addition, concern has been raised that wildlife market-acquired infections may be routinely under-ascertained in both primary [137] and secondary [138] care environments due to temporal disassociation between 


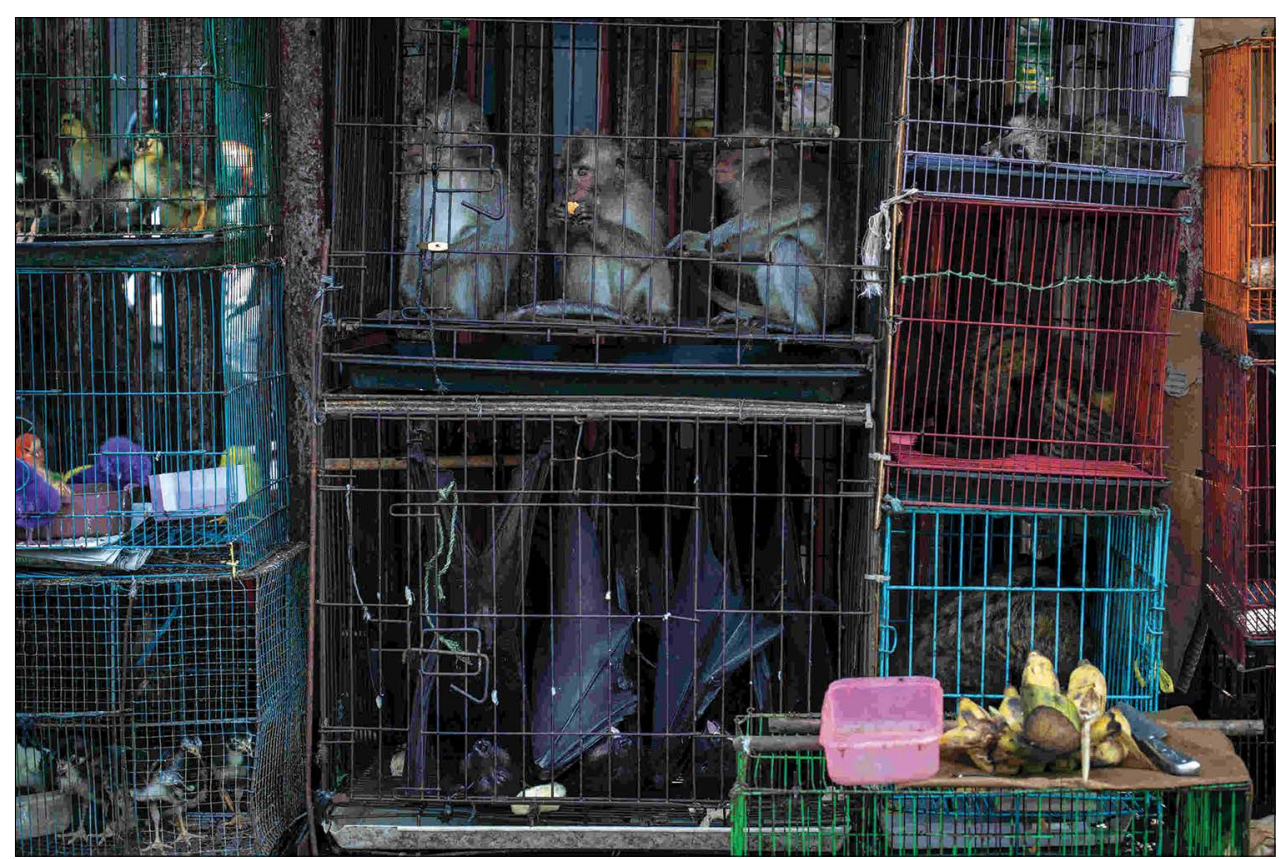

Figure-3: Wildlife market (birds and mammals), Jatinegara, Jakarta. (Credit: Aaron Gekoski, World Animal Protection).

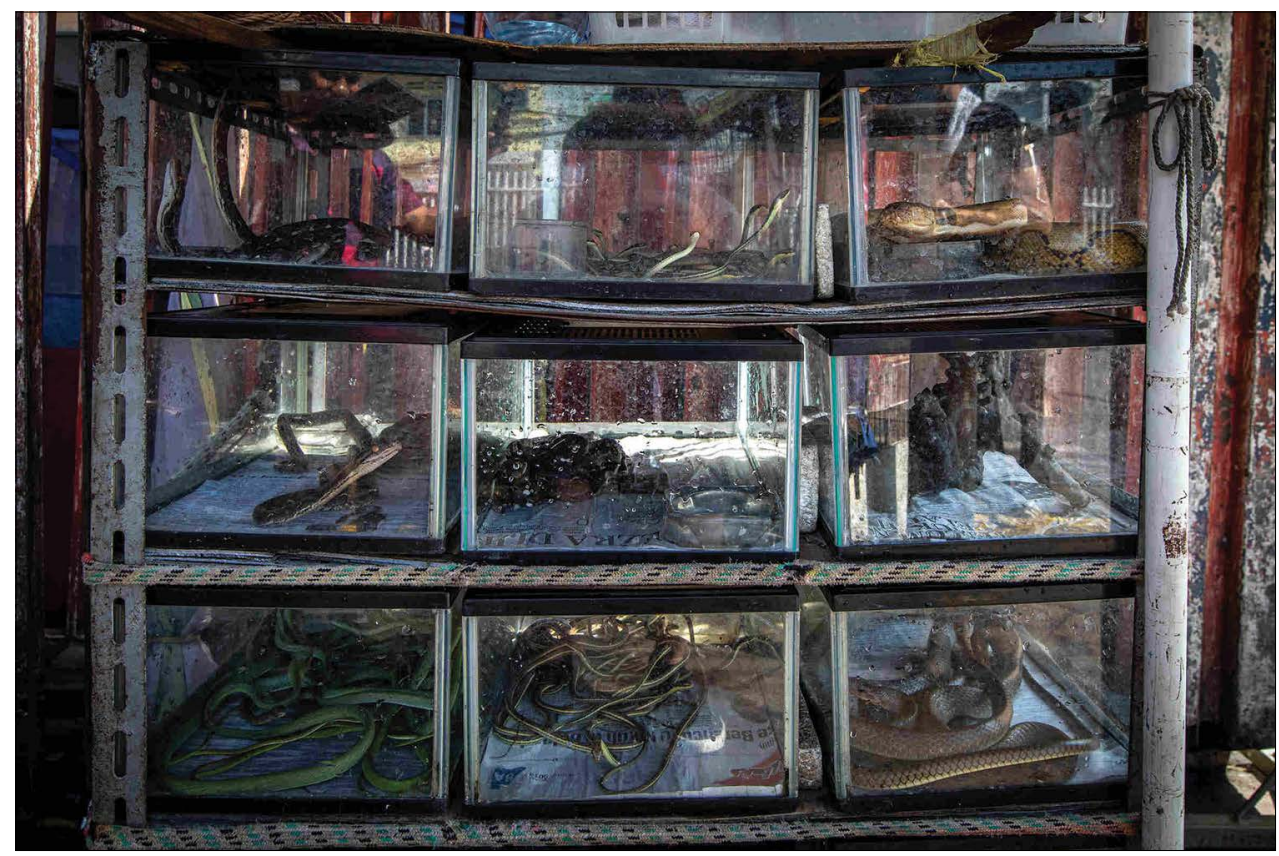

Figure-4: Wildlife market (reptiles), Jatinegara, Jakarta. (Credit: Aaron Gekoski, World Animal Protection).

attendance and onset of signs and symptoms, and because health-care professionals frequently do not enquire about possible contact between patients and zoonotic sources [137].

Many potentially pathogenic agents have been isolated from wild and captive animal gut and other tissue (Table-3). Furthermore, specific studies of diverse commercial captive breeding operations identified a range of pathogens, for example: Salmonella bacteria associated with pet turtle ranching [139]; Salmonella bacteria, Kalicephalus, Capillaria, Pinworm, Strongyloides ova, and Ascarid ova parasites associated with the wholesale pet trade environment [140]; Pseudomonas bacteria associated with marine turtle farming [141]; Salmonella bacteria associated with green iguana (Iguana iguana) farming [142]; and Acinetobacter, Aeromonas, Anaplasma, Bacteroides, Bordetella, Chlamydophila, Citrobacter, Clostridium, Elizabethkingia, Enterobacter, Enterococcus, Escherichia, Klebsiella, Leptospira, Lysobacter, Moraxella, Morganella, Mycoplasma, Proteus, Providencia, Pseudomonas, Salmonella, Serratia, Staphylococcus, Stenotrophomonas, Tsukamurella bacteria associated with pet ball python ranching [26]. A study of fecal samples from 741 zoo animals of 40 species of carnivores, hoofed mammals, primates, ratites, and reptiles found that $45 \%$ contained intestinal parasites, all of which were zoonotic [51]. Therefore, whether animals are wild-caught or captive-bred, pathogenic reservoirs remain important considerations. 


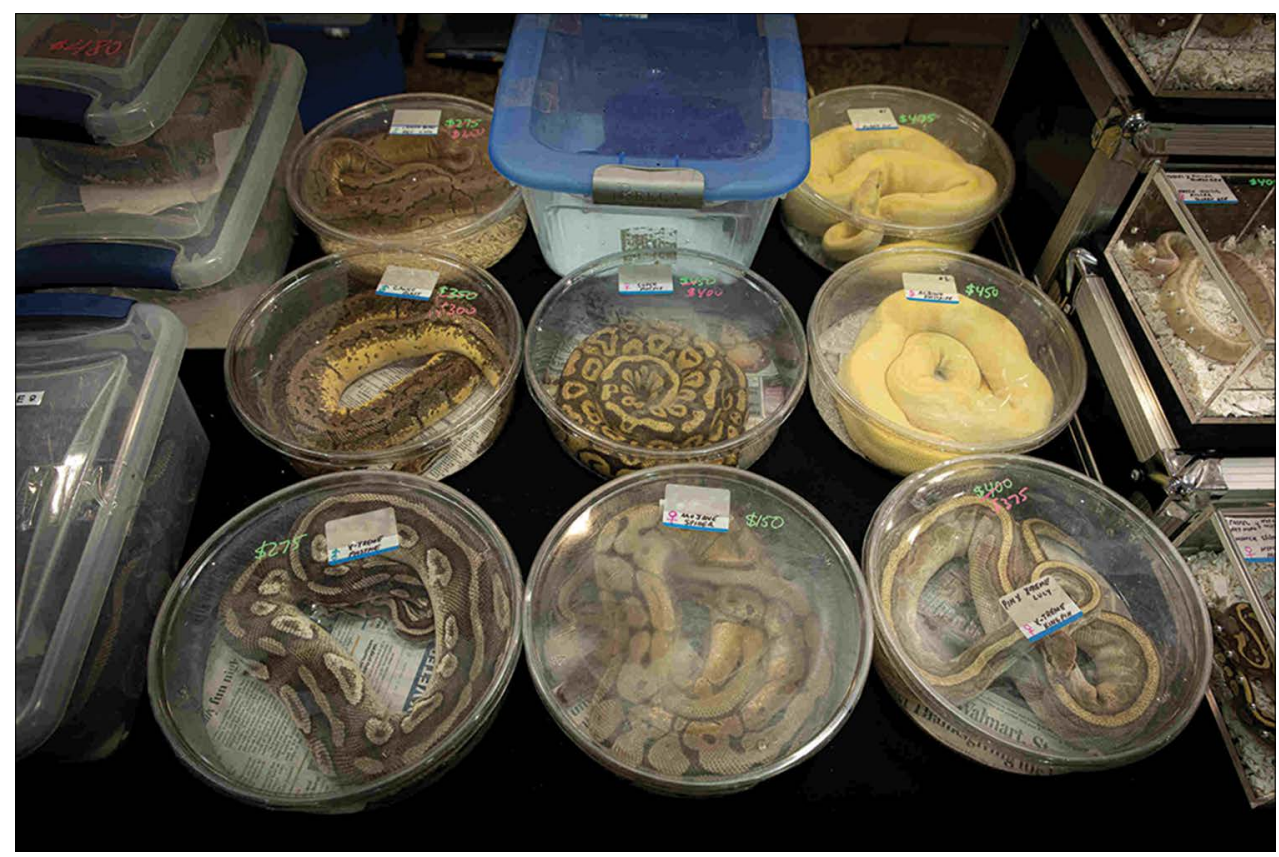

Figure-5: Wildlife market (reptiles), Memphis, USA. (Credit: Aaron Gekoski, World Animal Protection).

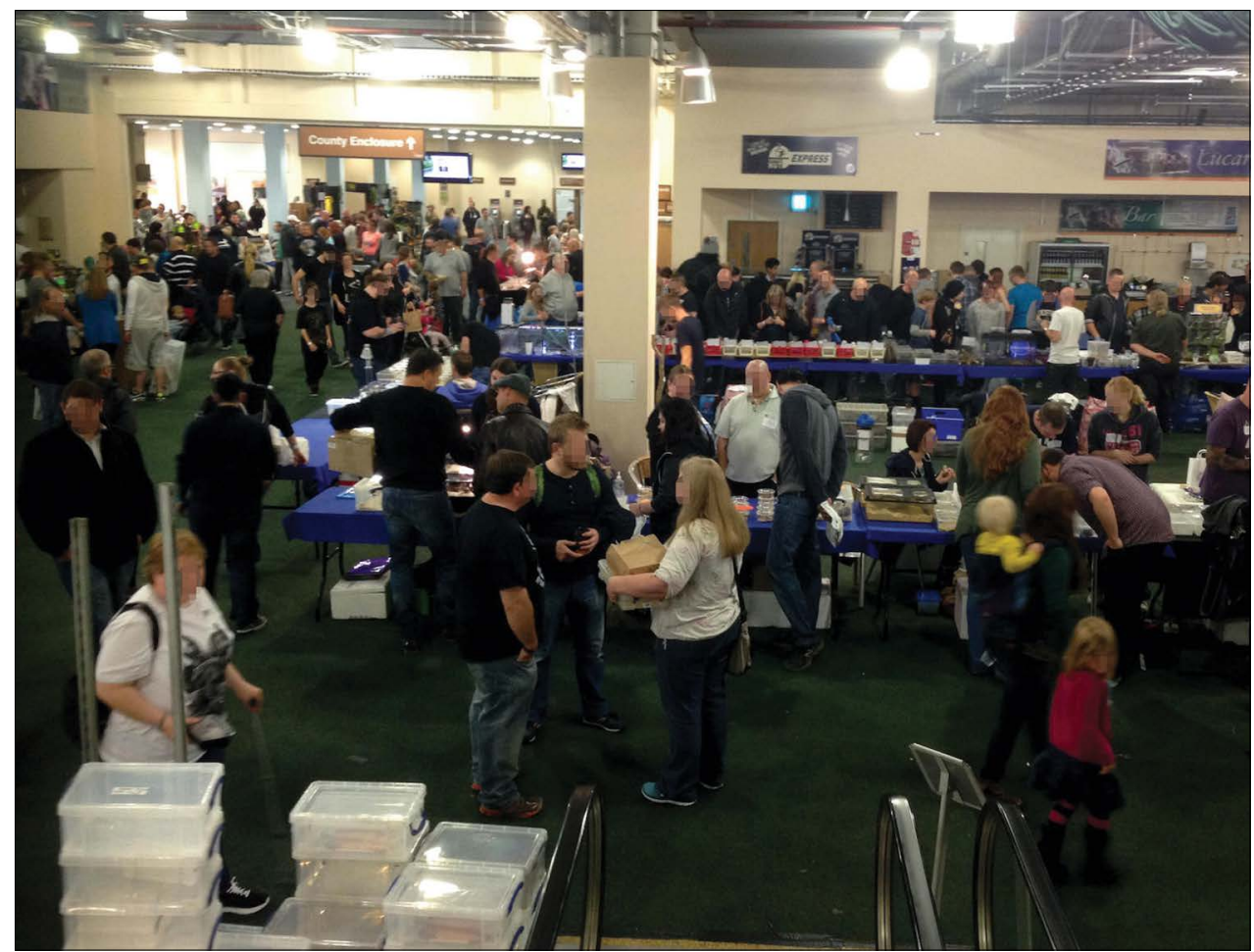

Figure-6: Wildlife/reptile market, Doncaster, UK. (Credit: Animal Protection Agency).

In addition, at least 138 viral infections are associated with pet animals [50]. Many potential human pathogenic micro-organisms, particles and parasites are inherently normal and commensal among other animal species [44], and practicably non-eradicable [44]. For example, commensal Salmonella bacteria in prey mice are known to harmlessly invade snake guts to be excreted and become human pathogens through fecaloral transmission [143,144]. A survey of Salmonella at a wildlife-pet market in Germany found novel reptile-associated S. ramatgan and S. subspecies-V to be present on door handles [44]. Despite use of liberal guidance on preventing infection, and provision of hand sanitizers to the public by organizers of Western pet markets, control of contaminants was found to be unresolvable $[2,44,45]$.

Many human and nonhuman animal diseases are vector-borne and have generated large epidemics, for example, West Nile virus (Flaviviridae spp.) is noted in amphibians and reptiles that originated in Africa and caused over 15,000 human deaths in United States alone [60]. Reasonably, many potentially pathogenic agents 


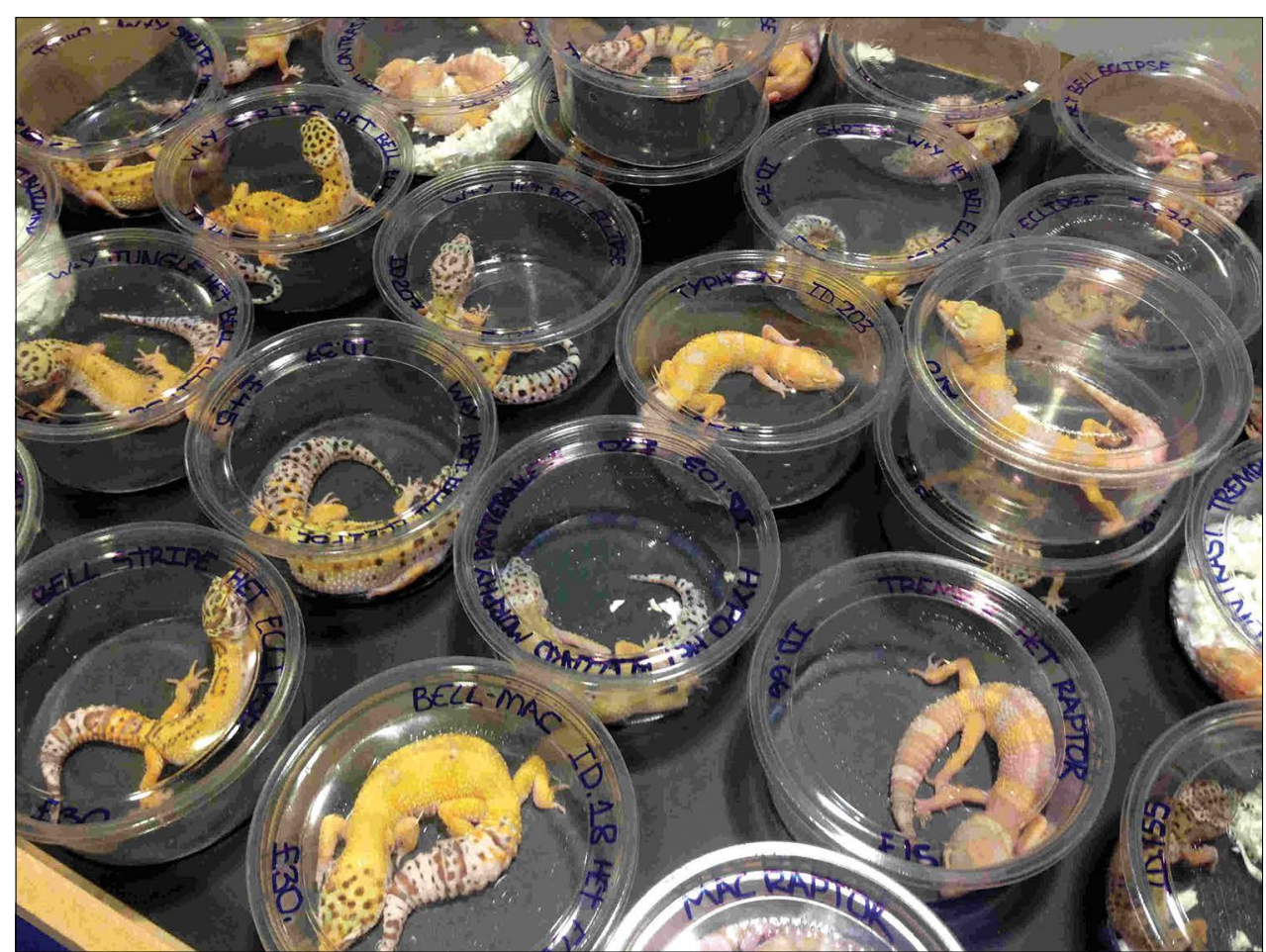

Figure-7: Wildlife/reptile market, Doncaster, UK. (Credit: Animal Protection Agency).

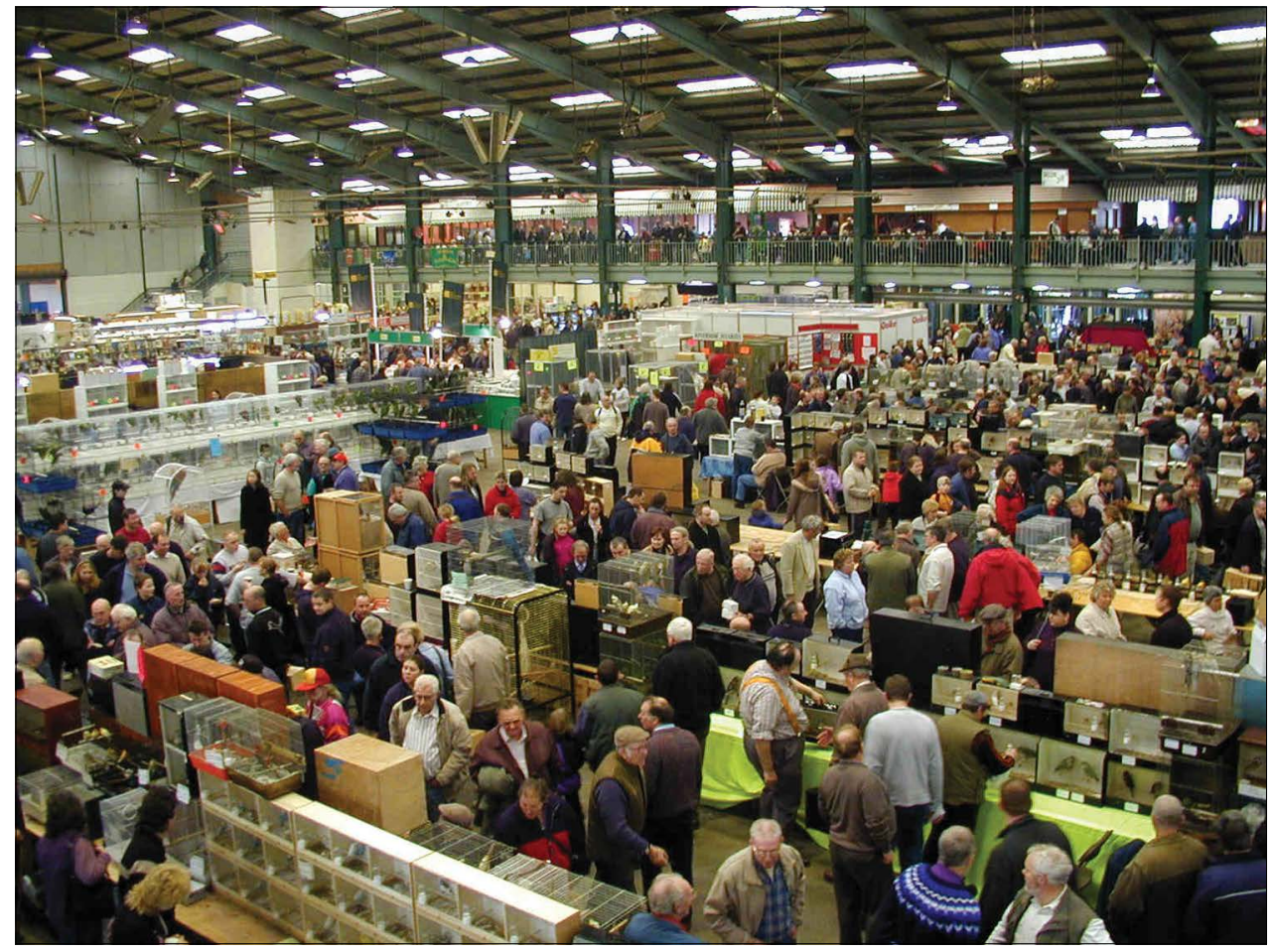

Figure-8: Wildlife market (birds), Stafford, UK. (Credit: Animal Protection Agency).

could transcend diverse hosts, for example, from invertebrates through to humans through the predator-prey food chain. Accordingly, microbial human pathogens and macroparasites may be presumed to occupy any animal from any world region or supply source, not least given the cross-contamination implications of wildlife markets and meta sectors (Figure-11).

Furthermore, many non-commensal and novel human pathogens may feasibly become introduced to wild-caught predatory animals that ingest diverse prey along with their microbiome and virome loads. For example, severe acute respiratory syndrome coronavirus 2 (SARS-Cov-2) coronavirus, or potentially a more serious pathogen such as Ebola virus, could become present in the guts of snakes that prey on virus-carrying bats. Although the role of snakes as a focal link in transmission of SARS-Cov-2 is ambiguous [145], their potential role continues to be scrutinized [146]. Thus, 


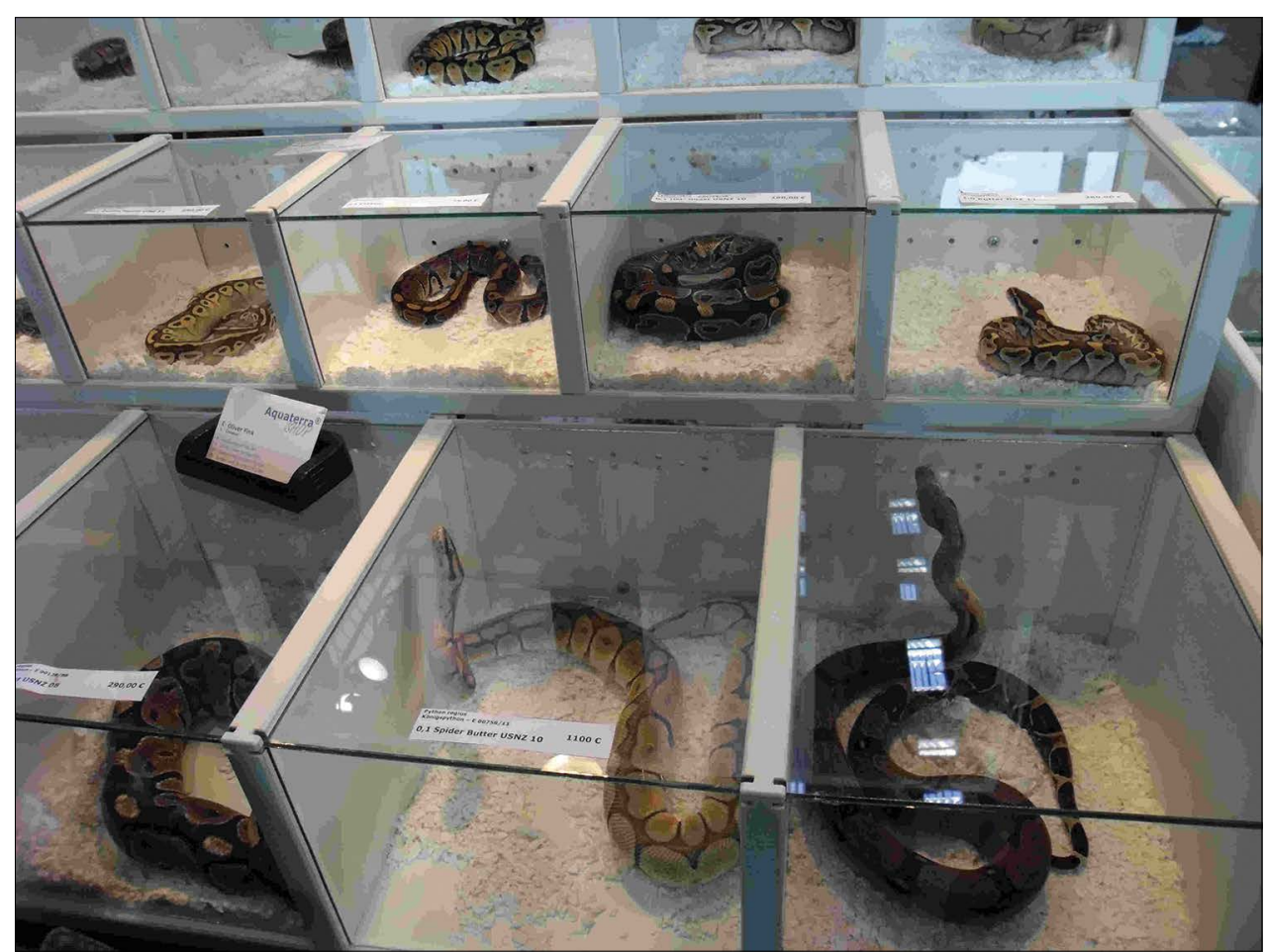

Figure-9: Wildlife market (reptiles/others), Hamm, Germany. (Credit: none).

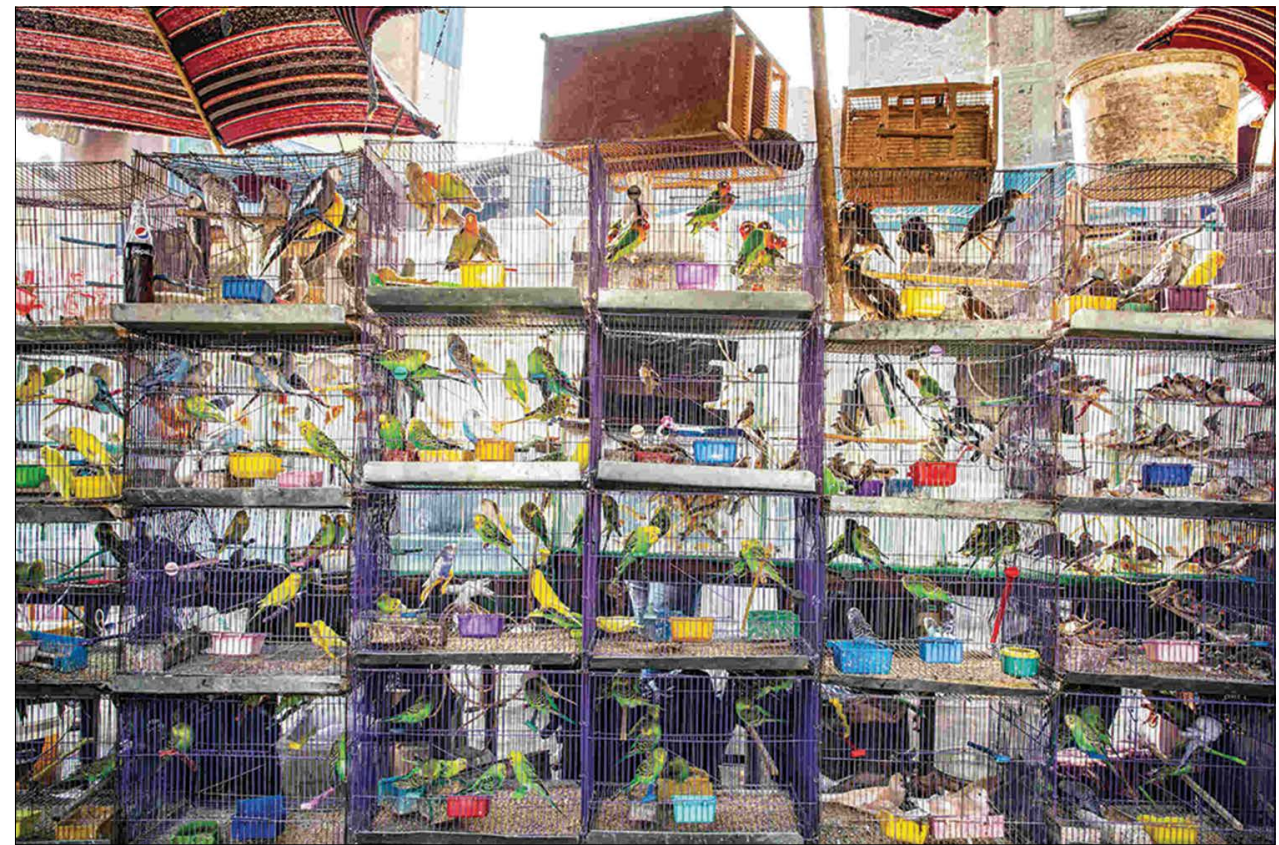

Figure-10: Wildlife market (birds), Cairo, Egypt. (Credit: Emily Marie Wilson shutterstock.jpg).

Table-3: Reported minimum number and class of potential human pathogens associated with animal wildlife.

\begin{tabular}{lccccccc}
\hline Animal class & \multicolumn{9}{c}{ Human pathogen class } & \multirow{2}{*}{ Sample references } \\
\cline { 2 - 7 } & Viral & Bacterial & Mycotic & Microparasitic & Macroparasitic & Prion & \\
\hline Invertebrates & 2 & 13 & 1 & 1 & 2 & - & {$[53-56]$} \\
Fishes & 6 & 10 & - & 1 & 7 & 1 & {$[44,45,50,57]$} \\
Amphibians & 3 & 34 & 3 & 2 & 5 & - & {$[44,45]$} \\
Reptiles & 5 & 36 & 3 & 5 & 4 & - & {$[26,27,44,45,51,58,59]$} \\
Birds & 40 & 28 & 3 & 2 & 17 & 1 & {$[44,45,50]$} \\
Mammals & 96 & 27 & 5 & 11 & & & \\
\hline
\end{tabular}

whether or not snakes have a direct relationship as a transmitter of SARS-Cov-2, they could nevertheless act as an incidental harborer and excreter of the virus, as has been reported possible for felines [147] and 


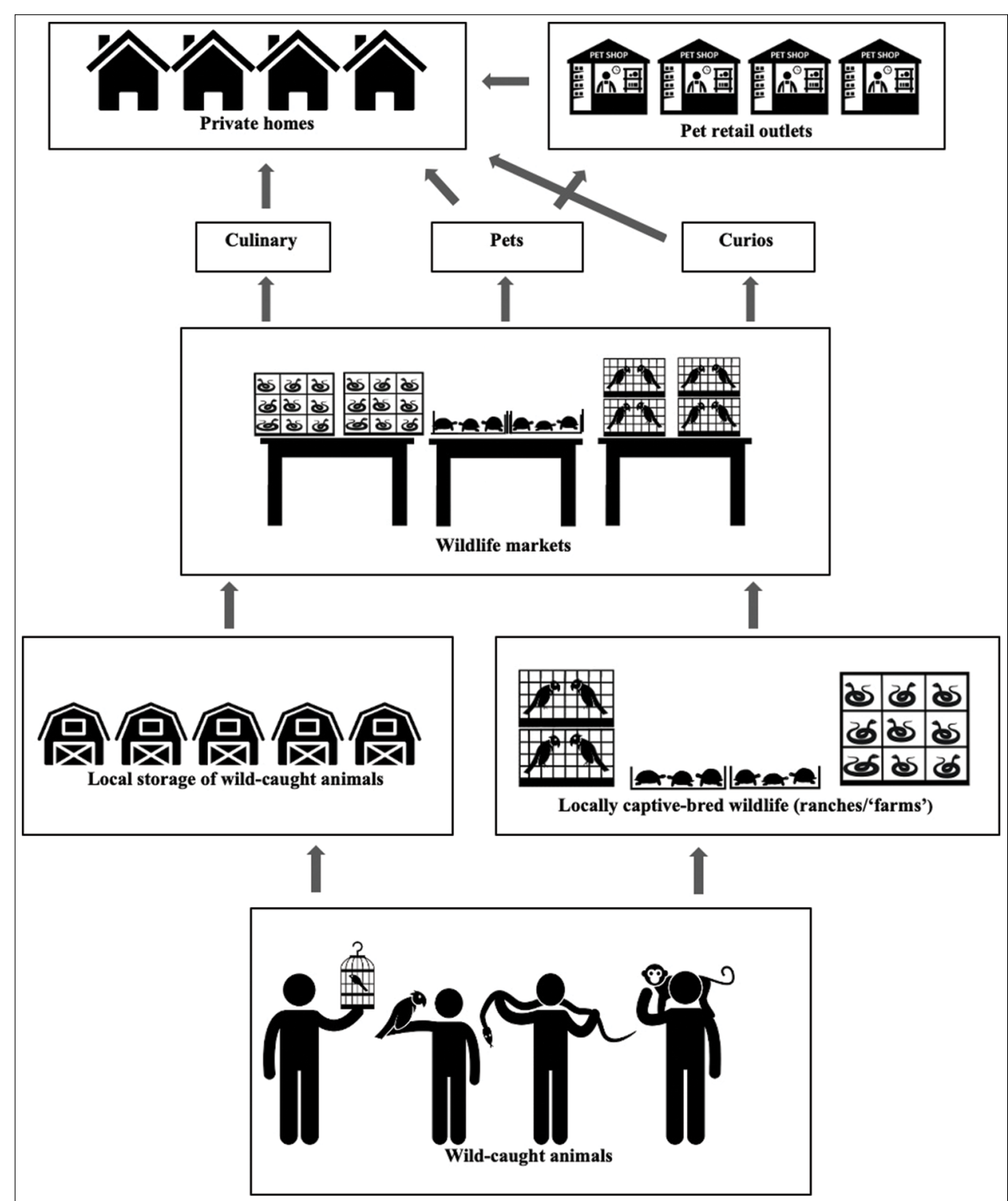

Figure-11: Basic guide to handling, transport, and storage dynamics regarding animals and wildlife markets, inferring significant recurrent stressful conditions for animals, and many opportunities for cross-contamination of potential pathogens. The reader should follow the diagram from the bottom ("Wild-caught animals") to top ("Private homes" and "Retail outlets").

humans [145]. It is unclear whether intermediary animals may act as transmitters of Ebola virus disease to humans [61,62]. However, Ebola virus is endemic in Africa [63] and Thailand [148], which are hubs of wildlife trade and international distributors to various global markets, including pets.

On a precautionary basis it cannot be ruled out that a wide range of potentially pathogenic prey-derived agents may long survive gut occupation in many animals, and thus viably persist lengthy storage, transportation, and housing conditions resulting in global distribution of established and novel entities from infection hubs to other (including naïve) regions $[11,39,44,52,149]$. Therefore, any animal (such as a snake) may be regarded as a potential atypical epidemiological source for pandemics. In addition, domesticated and other animals, including dogs, cats, chickens, and rabbits, could also become contaminated at wildlife markets by wild animals and potentially also act as ad hoc infection reservoirs ( $\mathrm{Li}$ and Jiang, unpublished).

Both culinary-based wet markets and wildlife markets involve direct and indirect handling of potentially infectious live animals and their derivatives. It is arguable that human and non-human animal exposure to body fluids due to handling of potentially infectious materials arising from butchering practices at wet markets may involve greater direct and indirect contamination risks than handling associated with wildlife markets. However, it is also arguable that human exposure to live animals at wildlife markets may involve proportionately significant coexisting risks in certain respects. For example, at wet markets, handling-associated contamination factors for potentially infectious animals and their derivatives are more intensive and shorter-term, whereas at wildlife markets such factors 
are less intensive but longer-term $[2,45]$. Furthermore, because pet animals acquired at wildlife markets are transferred to domestic environments, those animals may occupy households indefinitely, involving greater contact and exposure. Regardless, operators of market stalls frequently handle diverse animals, their derivatives, enclosures, and related materials, as well as engage with public visitors [45]. Accordingly, operator-environment-public interactions are commonplace and imply multiple significant opportunities for cross-contamination.

Table-3 provides a basic list of reported minimum number and class of potential pathogens associated with wildlife-pet animals. While reasonable data exist for vector-borne diseases [150], little specific investigatory work appears to have been done on invertebrate pet zoonoses, thus these animals are minimally represented in Table-3. Table-3 includes only potential pathogens and diseases that are frequently tabulated in published reports rather than all known potential pathogens and diseases. As indicated elsewhere, large numbers of viral, bacterial, mycotic, microparasitic, and macroparasitic agents are also known, for which benign or pathogenic nature has not been well determined. Table-4 provides a summary of example wildlife-associated infections and zoonotic epidemics or pandemics.

\section{Agricultural animal health}

Although agricultural animal health is not directly salient to this report, the issue is often strongly associated with animal-human cross-contamination epidemics and outbreaks, thus we provide brief mention and examples. Several pathogenic threats to agriculture from, especially imported, wildlife are well established. For example, since 1926, Newcastle disease (Paramyxovirus spp.) has been recognized as a viral infection typically associated with poultry [151]. The disease results in respiratory, neurological, and gastro-intestinal signs leading to loss of productivity or mortality variably up to $100 \%$ of animals; thus it is of significance to the agricultural industry, and its quarantine surveillance is mandatory [151]. Since 2000, heartwater disease or ehrlichiosis (Ehrlichia spp.) was identified as a vector-borne bacterial infection typically associated with ruminants [152] and was introduced to the United States through ticks (Amblyomma spp.) hosted by imported African wild pet tortoises [153]. The disease results in debilitation, loss of productivity, or mortality variably up to $100 \%$ of animals; thus its potential to become endemic in the US and invade large-scale cattle production remains highly concerning, and its potential impact has been managed using a combination of species bans and passports [152,154]. Since at least 1996, avian influenza H5N1 has affected regions globally, having originated from wild birds in Asia [155]. The disease results in various inflammatory, respiratory, gastro-intestinal, and other signs in birds, leading to loss of productivity or mortality, or imposed destruction of variably up to $100 \%$ of animals; thus its significance to the agricultural industry, and its quarantine surveillance is mandatory [156]. Relatedly, in 2005, an outbreak of avian influenza H5N1 was identified in imported consignments of quarantined pet birds of several species from Taiwan, bringing avian influenza to the United Kingdom [157]. Despite the imported consignments of wild pet birds having been deliberately isolated proximal to control specimens, the sentinel birds were unaffected, demonstrating that quarantine protocols must be considered circumspect even for well-known infectious agents.

Importantly, intensive animal production can involve significant stress and animal welfare-related issues that may increase susceptibility to introduce potentially pathogenic agents [115]. However, potential impacts on agricultural animal species from many wildlife-borne diseases are under-ascertained or unknown. Of current relevance, SARS-Cov-2 has recently been found in farmed mink in The Netherlands, resulting in the proactive culling of all animals [158].

\section{Quarantine and screening}

While quarantine of selected animals occurs for specific pathogens and diseases in some nations, the scope of such measures is minimalistic and arguably of low significance to the prevention or control for a myriad of possible wildlife-borne human and agricultural animal diseases. In addition, quarantine protocols for ectothermic animals (invertebrates, fishes, amphibians, and reptiles) are typically minimalistic or absent, which compounds prevention and control deficits. Quarantine screening for disease symptoms in wild or domesticated animals is usually limited to 30 days $[159,160]$. However, incubation times and disease onset latency for many infections and infestations (commonly associated with ectothermic animals) greatly exceeds this period [51], and infers minimum quarantine periods of 6 months are warranted for all wild as well as many domesticated animals [161-163], thus commonly shorter screening protocols of, for example, 30 days can be considered inadequate and involve disproportionate epidemiological risk. In addition, invertebrate vectors may harbor viable pathogens for several years [164], further raising risk concerns. These risks are well identified, for example, a United States government report on zoonotic disease and home security concluded that collaborative incongruities between official departments provided open gateways to importing disease [165].

Furthermore, deficiencies among microbial databases and technical processes, as well as application impracticalities, severely limit generalized screening abilities for both non-quarantined and quarantined animals. Accordingly, animals of uncertain origin and health state (which includes most examples of both wild-caught and captive-bred organisms) should be 


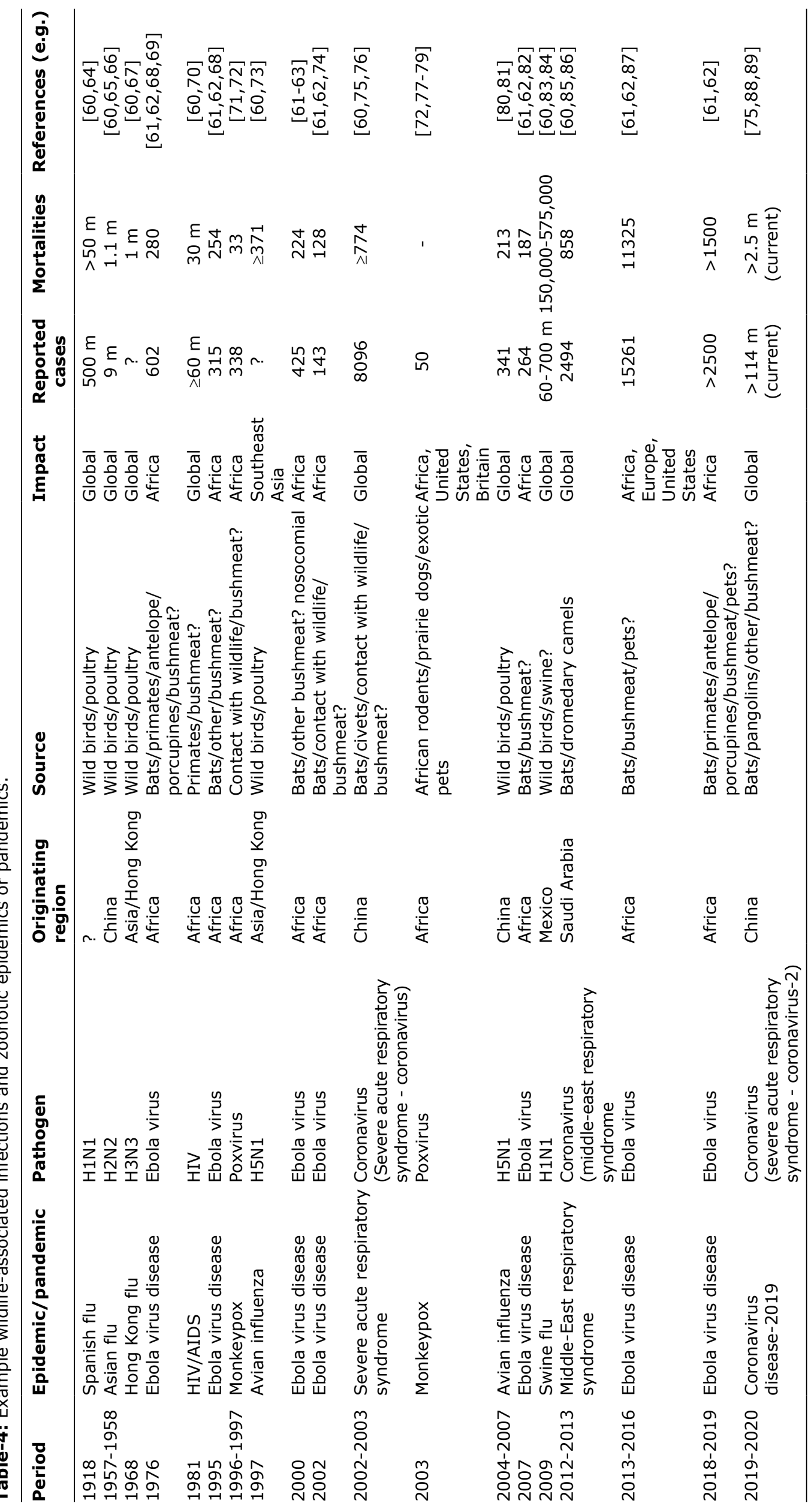


cautiously considered as contaminated with potentially relevant epidemic and pandemic agents. Relatedly, because wildlife-pet markets are regularly implicated in the supply chain for high street and online suppliers of wildlife as pets to private homes, endpoint acquirers should also be regarded as potentially naïve and vulnerable custodians of epidemiologically suspicious animals - a concern known as the "Trojan horse" factor [149].

\section{Wildlife trade scale and diversity}

Exact data regarding the number of wild-caught and captive-bred wild animals and species involved in trade are incomplete. In terms of legal trade, various reports offer some insight. For example, a study of Convention on International Trade in Endangered Species of Wild Fauna and Flora (CITES) listed vertebrates identified 5579 species (amphibians $=609[9 \%$ of extant amphibian species], reptiles $=1184[12 \%$ of extant reptile species], birds $=2345[23 \%$ of extant bird species], and mammals $=1441[27 \%$ of extant mammal species]) in international trade or $18 \%$ of globally known vertebrate species [166]. However, across all animal classes, including invertebrates and fishes, tens of thousands of animal species are thought to be traded globally $[167,168]$. At least 13,000 wildlife species are known to be included in the international exotic pet trade alone, with most species and individuals being wild-caught $[5,169]$. A study of CITES-listed species found that between 1975 and 2014 trade in plants, invertebrates, reptiles, birds, and mammals quadrupled from 25 million to 100 million whole organism equivalents annually [170]. A study of Southeast Asian wildlife exports over a 10-year period found that more than 35 million CITES-listed animals alone were shipped abroad, including to other Asian countries, as well as to Canada, United States, and Europe, of which approximately 30 million were wild-caught [171]. A 2017 study of imports to the United States for the years 2000-2013 found that 11 billion wildlife specimens, and further 977 million kilograms of wildlife were involved, mostly for the pet trade, of which $77.8 \%$ were wild-caught [5]. The USA is the single largest consumer of wildlife and may import over 224 million live animals annually [172].

Volume of animals traded at wildlife markets is unknown, although some examples are reported. A 2003 Chinese government raid of wildlife markets in Guangzhou removed over 838,000 wild animals [11]. A market in North Sulawesi, Indonesia, reportedly sold as many as 90,000 mammals annually [173]. Another survey of one market in Thailand conducted over 25 weekends found that more than 70,000 birds of 276 species were sold [174]. A 2014 study of seven cities in Guangdong and Guangxi Provinces in China identified more than 7000 animals and 97 species of (in majority order) reptiles (51\%), birds (21\%), and mammals (10\%) [4].

A 2012 survey of wildlife-pet markets selling amphibians and reptiles in Europe (Germany, Spain, and the United Kingdom) identified at least 179 species at three itinerant events [2]. A 2019 survey of wildlife markets in Togo, Africa, selling various animals found at least 286 species were involved [7]. In terms of illegal trade, more than 350 million wild plants and animals are exploited annually [175] $(=25 \%$ of total trade [11]), with an estimated economic value of 8-20 bn USD [166]. Some sectors of wildlife trade (i.e., amphibians and reptiles) may involve $44 \%$ illegal activity [176]. Accordingly, although potentially a single individual animal may causally introduce novel pathogens to a region or country leading to outbreaks, the vastness and poorly regulated nature of both legal and illegal wildlife trade involves unprecedented endemic pathogenic opportunities of scale and species diversity reservoirs for further epidemics or pandemics $[11,37]$.

\section{Legality, regulation, and enforcement at wildlife markets}

Wildlife markets are subject to varying degrees of legal regulation and enforcement. For example, in China wildlife markets are illegal and enforcement intermittent [177]. Since the SARS-CoV-2 coronavirus disease-2019 (COVID-19) outbreak, China, has reputedly increased monitoring and enforcement measures to maintain an effective ban [177]. In North America (Canada and the United States) wildlife markets are subject to variable regulation, in that cultural markets, based on overseas traditional culinary habits, are endemic and permitted in numerous areas, but are subject to limited public health conditions, although greater regulation on both animal welfare and public health grounds is being pursued in some cases. In Europe (e.g., Germany, Czech Republic, The Netherlands, and Spain) despite wildlife markets being typically legal, illegalities occur involving sale of protected species $[2,34,35]$. In the United Kingdom, the trading of any vertebrate animals as pets at markets is unlawful, and in recent decade's occurrence has been largely eliminated, although some British local authorities continue to fail to act to curtail illegal and open selling [2].

\section{Global one-health dynamics}

Animals for wildlife markets may be wildcaught or captive-bred within their country of origin and sold locally, nationally, or globally $[1,2,4,6,7,9,12-18,26,28,33-35,37]$. Welfare of animals at all points in the exploitative chain can be described as poor to abusively brutal, and such treatment is known to impact immunocompetence, susceptibility to infection, and pathogen shedding issues among affected animals [113,115,178-183]. Relatedly, direct mixing of diverse species and individual animals, as well as their confinement in close proximity, probably propagates cross-pollination of commensal, opportunistic and pathogenic micro-organisms and particles, presenting many opportunities for spill-over of potentially infectious agents $[11,40,60,140,184,185]$. 
Pathogen spill-over invites manifest risks of generating epidemics and pandemics of highly diverse backgrounds.

Identification of wild-caught versus captive-bred animals is challenging and false and misleading claims regarding origin are a matter of concern [186]. Regardless, even where animals may be identifiable as captive-bred and locally sourced, common prior mixing with animals of uncertain origin and health-state increases contamination or infection risk and complicates biosecurity and the tracing of epidemiological origins $[140,149]$. These dynamics infer that the multiple handling, transportation, and disturbance events endemic to wildlife markets are relevant to animal welfare and to potentially diverse wildlife-associated pathogens, which should be considered viably present in all animals regardless of apparent source and their endpoint sale circumstances (Figure-11).

Modern transportation allows worldwide distribution of animals within very short periods after capture, handling, and storage, thus also enabling rapid global dispersal of large numbers of probably stressed, immunocompromised, or diseased individuals as well as harbored pathogens $[11,39,44,149,184]$. Moreover, wildlife markets and associated trade hubs, being dependent on high footfall business generally occupy centers of significant human population densities, encouraging possibly rapid liberal dissemination of pathogenic agents $[2,44,45]$. Disease and human population modeling indicate that emerging infectious diseases are more likely to occur in more densely populated areas, and where there is greater diversity of wildlife [40]. Around 1.7 million viruses [187,188], and many additional bacterial, mycotic, parasitic, and other potentially pathogenic entities are thought to exist in wildlife reservoirs that could invade humans $[44,189,190]$. Extant human behavior and practices are currently and regularly narrowing historically protective distances between atypical pathogens and naïve human or agricultural populations [150]. As indicated earlier, major animal, and public health outbreaks have already been linked to wildlife markets as their probable originating sources, including avian influenza, swine flu, monkeypox, SARS-CoV-1, and most recently SARS-CoV-2/COVID-19. Other possible and perhaps anticipated, outbreaks from wildlife markets include further novel coronaviruses, and arguably far more seriously, ebolaviruses, and hantaviruses.

Warnings have enduringly persisted regarding anthropogenic deforestation and other habitat destruction; commercial exploitation of wildlife biodiversity; abusive practices towards animals; the role of modern globalized transportation in allowing easy encroachment of humans into relatively naïve ecosystems as well as the facilitation of rapid pathogen spread from remote areas to domestic environments; and threats from emergent diseases associated with wildlife trade and wet/wildlife market conditions
[2,11,39,40,44,52,60,131,132,149,185,191-194]. Accordingly, animal, human, and environmental health and welfare are intimately connected within the "one health, one welfare, and one biology" concept $[15,60,115,192,193,195]$.

A raft of recent calls has arisen from scientific, animal welfare, conservation, international governmental, and popular communities for closure of existing wildlife markets for all purposes, and prohibitions against their future emergence [13,120,48,196-201]. Some have argued that bans on wildlife trade could be of limited effect regarding prevention and control of future epidemics and pandemics, and also counter-productive against biodiversity conservation [202,203]. However, complete well-enforced wildlife trade bans are the accepted and proven gold-standard mechanism for prevention and control of animal welfare abuses, public health epidemics and pandemics, and threats to biodiversity conservation [134,204-210].

Governments are traditionally locked-in to protocols that allow disproportionate weight and strong influence to commercial interests on the presumed basis of their local, regional, international or global value, without taking proportionate account of animal welfare, public health, environmental and economic harms and implications inherent to wildlife trade practices or relevant opposing perspectives [211-213]. This disproportionality of representative weight reflects a paradigm responsible for historical and current inaction to resolve global issues with serious problematic outcomes and extensive amelioratory costs. A major paradigmatic shift is warranted in which precautionary principles constitute the mainstay of government actions, inferring that wildlife exploitative practices are barred until or unless independently and scientifically verified as possessing low or no negative impacts [214]. This precautionary principle of operation is enshrined in the concept of "positive lists" (also known as "green lists," "reverse lists" or "white lists") that provide the normal foundation for almost all accepted responsible commercial and other practices (e.g., medicine, dentistry, drug development, pilotage, vehicle or vessel safety, and construction) and have been demonstrated to be effective and economic measures for regulating wild animals in captivity [214].

\section{Conclusion}

Wildlife-pet markets, although standalone phenomena, also have ties to the endpoints of wider relevant issues, including anthropogenic habitat loss, ecological disturbance, encroachment, globalization, transport facilitation, trade, wildlife capture, captive-breeding, culinary habits, and wildlife-pet keeping. These elements involve a range of negative factors from poorly moderated introductions of humans to atypical environments, through to removal of wildlife from ecologically stable systems, to placement of animals into abnormal conditions of captivity in commerce and the home. Individually and cumulatively, 
these factors, and the diversity of divisional elements within each, probably constitute the primary causes of suffering, morbidity, and mortality among wildlife-pet animals and the emergence of wildlife-associated human and agricultural epidemics and pandemics.

Epidemiological trace-back indicates that the majority of human and key agricultural epidemic and pandemic diseases are directly or indirectly causally linked to wildlife (whether direct, indirect, or vector-borne) [150]. However, it is important to iterate that primary or incidental involvement of wildlife species in human or agricultural epidemics and pandemic should not be considered a reason for their demonization [215]. Although particular species groups may be correctly regarded as primary focal reservoirs of human pathogenic agents (e.g., bat-associated viruses and reptile-associated bacteria), all wild animals including invertebrates (e.g., arthropods, molluscs, and crustaceans), fishes (fishes, eels, and rays), amphibians (e.g., frogs, toads, and caecilians), reptiles (e.g., chelonian, lizards, and snakes), birds (e.g., parrots, finches, and hawks), and mammals (e.g., rodents, marsupials, and primates) may act as primary or secondary sources of emerging infectious and zoonotic disease.

Southeast Asian, Indian, cultural, North American, Latin American, European, and African wildlife markets have long been associated with both animal welfare and public health concerns, regarding inconsiderate and abusive conditions of captivity and epidemiological risk and manifest emergent disease - including specific outbreaks and national epidemics and global pandemics. Whether or not the recent example of SARS-Cov-2 virus may have emerged only at Southeast Asian wildlife markets or potentially from elsewhere, it remains probable that alternative infectious agents across all pathogenic classes viably occupy wildlife markets globally.

While there are notable degrees of variability in less versus more developed countries and regions regarding aesthetics, animal husbandry, animal sourcing, hygiene, and regulation across and between Southeast Asian, cultural, Western and African wildlife markets, this variation is, in our view, operationally modest. Accordingly, key problematic features, including: Sourcing wild animals (whether wild-caught or captive-bred), unacceptable standards of animal welfare, extent and diversity of potentially pathogenic animal biomes and viromes, interspecies cross-contamination, major quarantine and screening inabilities, and complexities of microbial transmission, remain intact to all types of wildlife market. Therefore, in our view, there are no significant grounds for regarding events in well-developed areas as harboring significantly lower risks to animal welfare or public health compared with other hosting areas, and that these problems are incapable of amelioration within a permissive control system.

Wildlife markets constitute a relatively small component of wildlife culinary consumption [177], in that they may involve hundreds of thousands to several millions of animals annually, whereas wildlife trade overall involves hundreds of millions of animals annually (see also "Wildlife trade scale and diversity") and comprise a relatively low component of overall trade in wildlife for pets. Historical and current permissive regulation, as well as poorly enforced prohibitive regulation at all levels, has failed to provide reasonable control of wildlife markets and the prevention of common regional or global major and catastrophic animal welfare and public health problems.

China has been variously criticized concerning inadequate historical action to maintain domestic bans imposed on wildlife markets because of their role in poor animal welfare and as potential hubs of emergent disease. However, such criticisms can also be levied at all globally relevant regions in which wildlife markets occur - perhaps most ironically at the China-accusatorial Western commentators and governments that have themselves failed to act decisively against wildlife markets within their own domains. Arguably, governments of regions that continue to accommodate wildlife markets should strive to set exemplary measures for managing animal welfare and controlling emergent diseases. Western-nation failings of example are arguably similarly responsible for coexisting issues of international concern including gross animal welfare abuses [2,140,205,216,217]; public health matters endemic to wildlife trade generally $[5,11,44,45,131,132,134,184,218-223]$, antimicrobial resistance [224-226]; and ecological matters including threats to species conservation, habitat loss and shifts from natural habitat to agricultural land use, invasive alien organisms, and negative economic impacts [40,49,190,196,227-233].

\section{Recommendations}

We have considered three elements in our recommendations: (1) Animal welfare: Prevention of abuses; (2) Public health: Prevention of epidemics and pandemics at source; and (3) Wildlife trade dependents: Supporting local people. Although our proposed measures are similar and overlapping for elements 1 and 2, we have itemized these separately because particular readers and actors may wish to consider each subject independently.

1. Animal welfare: Prevention of abuses

We propose that the only pragmatic amelioratory measures for prevention and control of inadequate husbandry or extreme and brutal abusive treatment of animals inherent to wildlife markets are government sanctioned bans on the collection, transportation, storage, keeping, sale, or slaughter of wild-caught or captive-bred wildlife at markets for pet, culinary, medicinal, and other purposes. It is administratively imperative, and economically prudent that bans are emboldened with strong monitoring and enforcement.

2. Public health: Prevention of epidemics and pandemics at source 
We propose that the only pragmatic amelioratory measures for prevention and control of future anthropogenic wildlife-market-associated epidemics and pandemics from originating hubs of contamination are government sanctioned bans on the collection, transportation, storage, keeping, sale, or slaughter of wild-caught or captive-bred wild animals for pet, medicinal, culinary, and other commercial purposes. It is administratively imperative, and economically prudent that bans are emboldened with strong monitoring and enforcement.

3. Wildlife trade dependents: Supporting local people

Bans may have significant impacts on at least some former economic dependents within local wildlife supply sectors. Arguably, such impacts may be comparable to any sector that faces disbenefits from income reduction or collapse of corresponding commercial activities from bans that affect diverse businesses and cottage industries. Whether such commercial activities inherently fail or are curtailed by government is not new, and support for those formerly dependent on local wildlife can be considered in accordance with existing formal remedies. However, proportionate essential support for previous dependents of wildlife trade can be viewed as a potentially important investment against novel disease outbreaks as well as a deterrence from illegal activity.

\section{Authors' Contributions}

CW: Conceptualization, methodology, supervision, drafted the manuscript. CW and CS: Conducted the research, data preparation, drafted and revised the manuscript. Both authors have read and approved the final manuscript.

\section{Acknowledgments}

We would like to thank the People for the Ethical Treatment of Animals for funding this study. We also thank Dr. Sandra Altherr, Dr Neil D’Cruze, Dr Fredric L. Frye, Alejandra Goyenechea, Michèle Hamers, Danielle Katz, Rob Laidlaw, Dr Peter Li, Dawn Peacock, and Pei F. Su, for their assistance in providing information relevant to wildlife markets.

\section{Competing Interests} interests.

The authors declare that they have no competing

\section{Publisher's Note}

Veterinary World (Publisher of International Journal of One Health) remains neutral with regard to jurisdictional claims in published and institutional affiliation.

\section{References}

1. Van Song, N. (2008) Wildlife trading in Vietnam, situations, causes and solutions. J. Environ. Dev., 17(2): 145-165.
2. Arena, P.C., Steedman, C. and Warwick, C. (2012) Amphibian and Reptile Pet Markets in the EU: An Investigation and Assessment. p52. Available from: https:// www.apa.org.uk/pdfs/amphibianandreptilepetmarketsreport.pdf. Retrieved on 25-05-2020.

3. Shepherd, C.R. (2012) Observations of small carnivores in Jakarta wildlife markets, Indonesia, with notes on trade in javan ferret badger Melogale orientalis and on the increasing demand for common palm civet Paradoxurus hermaphroditus for civet coffee production. Small Carniv. Conserv., 47: 38-41.

4. Chow, A.T., Cheung, S. and Yip, P.K. (2014) Wildlife markets in South China. Hum. Wildl. Interact., 8(1): 1-11.

5. Smith, K., Zambrana-Torrelio, C., White, A., Asmussen, M., Machalaba, C., Kennedy, S., Lopez, K., Wolf, T., Daszak, P. and Travis, D. (2017) Summarizing US wildlife trade with an eye toward assessing the risk of infectious disease introduction. EcoHealth, 14(1): 29-39.

6. Suzuki, D., Fuse, K., Aizu, M., Yoshizawa, S., Tanaka, W., Araya, K. and Praxaysombath, B. (2015) Reptile diversity in food markets in Laos. Curr. Herpetol., 34(2): 112-119.

7. D'Cruze, N., Assou, D., Coulthard, E., Norrey, J., Megson, D., Macdonald, D.W., Harrington, L.A., Ronfot, D., Segniagbeto, G.H. and Auliya, M. (2020) Snake oil and pangolin scales: Insights into wild animal use at "Marché des Fétiches" traditional medicine market, Togo. Nat. Conserv., 39: 45-71.

8. Latinne, A., Saputro, S., Kalengkongan, J., Kowel, C.L., Gaghiwu, L., Ransaleleh, T.A., Nangoy, M.J., Wahyuni, I., Kusumaningrum, T. and Safari, D. (2020) Characterizing and quantifying the wildlife trade network in Sulawesi, Indonesia. Glob. Ecol. Conserv., 21: e00887.

9. Marano, N., Arguin, P.M. and Pappaioanou, M. (2007) Impact of globalization and animal trade on infectious disease ecology. Emerg. Infect. Dis., 13(12): 1807.

10. TRAFFIC. (2010) Demand for Frogs Rising in West Africa. Traffic International. Available from: https://www. traffic.org/news/demand-for-frogs-rising-in-west-africa. Retrieved on 25-05-2020.

11. Karesh, W.B., Cook, R.A., Bennett, E.L. and Newcomb, J. (2005) Wildlife trade and global disease emergence. Emerg. Infect. Dis., 11(7): 1000-1002.

12. Choi, M., Morin, C., Scheftel, J., Vetter, S., Smith, K., Lynfield, R. and Team, V.I.I. (2015) Variant influenza associated with live animal markets, Minnesota. Zoonoses Public Health, 62(5): 326-330.

13. Kolby, J. (2019) Misuse of Wildlife Trade Data Jeopardizes Efforts to Protect Species and Combat Tracking Mongabay. Available from: https://www.news.mongabay.com/2019/10/ misuse-of-wildlife-trade-data-jeopardizes-efforts-to-protect -species-and-combat-trafficking-commentary. Retrieved on 25-05-2020.

14. Pressly, L. (2015) The Country that Blends Endangered Frogs, BBC News. Available from: https://www.bbc.co.uk/ news/magazine-32718813. Retrieved on 25-05-2020.

15. Su, S., Cassey, P., Vall-Llosera, M. and Blackburn, T.M. (2015) Going cheap: Determinants of bird price in the Taiwanese pet market. PLoS One, 10(5): e0127482.

16. Williams, V.L., Moshoeu, T.J. and Alexander, G.J. (2016) Reptiles sold as traditional medicine in Xipamanine and Xiquelene markets (Maputo, Mozambique). S. Afr. J. Sci., 112(7-8): 1-9.

17. Nijman, V., Spaan, D., Rode-Margono, E.J., Wirdateti. and Nekaris, K.A.I. (2017) Changes in the primate trade in Indonesian wildlife markets over a 25 -year period: Fewer apes and langurs, more macaques, and slow lorises. $\mathrm{Am}$. J. Primatol., 79(11): e22517.

18. Nijman, V. and Bergin, D. (2017) Reptiles traded in markets for medicinal purposes in contemporary Morocco. Contrib. Zool., 86(1): 39-50.

19. Anon. (2020) Exotic Bird Event. Ten Times Online. Available from: https://www.10times.com/company/ 
exotic-bird-event. Retrieved on 25-05-2020.

20. Anon. (2020) Reptile Events Calendar. Reptiles Magazine. Available from: https://www.reptilesmagazine.com/reptile-events-calendar. Retrieved on 25-05-2020.

21. Anon. (2020) Zwolse Birdmarket. $71^{\text {st }}$ ed. De Zwolse Vogelmarkt. Available from: https://www.zwollevogelmarkt.nl/english. Retrieved on 25-05-2020.

22. Anon. (2020) Canadian Pet Expo: Aquatic Zone. Canadian Pet Expo. Available from: https://www.canadianpetexpo.ca/ highlights/aquatic-zone. Retrieved on 25-05-2020.

23. Gardner, M. (2020) Upcoming American koi Show Dates, Nishikigoi Life. Available from: http://www.nishikigoi. life/2018/06/27/upcoming-american-koi-show-dates. Retrieved on 25-05-2020.

24. Anon. (2020) Canadian National Cage Bird Show and Expo. Hagen Avicultural Research Institute. Available from: https://www.hari.ca/hari/global-networking/events-conferences/canadian-national-cage-bird-show-expo. Retrieved on 25-05-2020.

25. Anon. (2020) Canadian Reptile Breeders Expo. Canadian Pet Expo. Available from: https://www.canadianpetexpo.ca/ canadian-reptile-breeders-expo. Retrieved on 25-05-2020.

26. D'Cruze, N., Bates, J., Assou, D., Ronfot, D., Coulthard, E., Segniagbeto, G.H., Auliya, M., Megson, D. and Rowntree, J. (2020) A preliminary assessment of bacteria in "ranched" ball pythons (Python regius), Togo, West Africa. Nat. Conserv., 39: 73-86.

27. D'Cruze N., Paterson S., Green J., Megson D., Warwick C., Coulthard E., Norrey J., Auliya M. and Carder G. (2020) Dropping the ball? The welfare of ball pythons traded in the EU and North America. Animals, 10(3): 413.

28. Kock, R.A., Karesh, W.B., Veas, F., Velavan, T.P., Simons, D., Mboera, L.E., Dar, O., Arruda, L.B. and Zumla, A. (2020) 2019-nCoV in context: Lessons learned? Lancet Planet. Health, 4(3): e87-e88.

29. People for the Ethical Treatment of Animals. (2020) Live Animal Markets Open, People for the Ethical Treatment of Animals. Available from: https://www.investigations. peta.org/indonesia-thailand-wet-markets. Retrieved on 16-05-2020.

30. People for the Ethical Treatment of Animals. (2020) Live Animal Markets in California (2 Reports). People for the Ethical Treatment of Animals. p4.

31. People for the Ethical Treatment of Animals. (2020) Live Animal Markets in New York. People for the Ethical Treatment of Animals. p6.

32. People for the Ethical Treatment of Animals. (2020) Live Animal Markets in Illinois. People for the Ethical Treatment of Animals. p5.

33. Krishna, V.V., Darras, K., Grass, I., Mulyani, Y.A., Prawiradilaga, D.M., Tscharntke, T. and Qaim, M. (2019) Wildlife trade and consumer preference for species rarity: an examination of caged-bird markets in Sumatra. Environ. Dev. Econ., 24(4): 339-360.

34. Auliya, M., Altherr, S., Ariano-Sanchez, D., Baard, E.H., Brown, C., Brown, R.M., Cantu, J.C., Gentile, G., Gildenhuys, P. and Henningheim, E. (2016) Trade in live reptiles, its impact on wild populations, and the role of the European market. Biol. Conserv., 204(Part A): 103-119.

35. Altherr, S., Brückner, J. and Mackensen, H. (2010) Mangelhafte Umsetzung der BMELV-Tierbörsen-Leitlinien Eine Bestandsaufnahme. Available from: https://www. prowildlife.de/wp-content/uploads/2016/02/BoersenDoku_2010_final_low_sol.pdf. Retrieved on 16-05-2020.

36. World Animal Protection. (2019) Risky Business: The Unregulated Exotic Pet Trade in Canada. Available from: https:// www.worldanimalprotection.ca/sites/default/files/media/ca - en_files/wap_exotic_pets_in_ canada report_final_forweb oct 3 2019.pdf. Retrieved on 02-06-2020.

37. Daut, E.F., Brightsmith, D.J. and Peterson, M.J. (2015) Role of non-governmental organizations in combating illegal wildlife pet trade in Peru. J. Nat. Conserv., 24: 72-82.
38. Lin, J. (2005) Tackling Southeast Asia's illegal wildlife trade. Sybil, 9: 191-208.

39. Bengis, R., Leighton, F., Fischer, J., Artois, M., Morner, T. and Tate, C. (2004) The role of wildlife in emerging and re-emerging zoonoses. Rev. Sci. Tech., 23(2): 497-512.

40. Allen, T., Murray, K.A., Zambrana-Torrelio, C., Morse, S.S., Rondinini, C., Di Marco, M., Breit, N., Olival, K.J. and Daszak, P. (2017) Global hotspots and correlates of emerging zoonotic diseases. Nat. Commun., 8(1): 1124.

41. Kitade, T., Naruse, Y. (2020) Crossing the Red Line: Japan's Exotic Pet Trade, Tokyo, Japan. Available from: https:// www.traffic.org/site/assets/files/12923/crossing_the_red_ line en-forweb.pdf. Retrieved on 28-06-2020.

42. Pet Industry Joint Advisory Council Canada. (2020) Supporting Pet Businesses and the Advancement of Animal Care. PIJAC Canada. Available from: https://www.pijaccanada.com. Retrieved on 02-06-2020.

43. Warwick, C., Jessop, M., Arena, P., Pilny, A. and Steedman, C. (2018) Guidelines for inspection of companion and commercial animal establishments. Front. Vet. Sci., 5: 151 .

44. Warwick, C., Arena, P., Steedman, C. and Jessop, M. (2012) A review of captive exotic animal-linked zoonoses. $J$. Environ. Health Res., 12(1): 9-24.

45. Warwick, C., Arena, P.C. and Steedman, C. (2012) Visitor behaviour and public health implications associated with exotic pet markets: An observational study. JRSM Open, 3(9): 63.

46. Warwick, C., Toland, E. and Glendell, G. (2005) Why legalise exotic pet markets. Vet. Times, 35: 6-7.

47. Green, J., Coulthard, E., Megson, D., Norrey, J., Norrey, L., Rowntree, J.K., Bates, J., Dharmpaul, B., Auliya, M. and D'Cruze, N. (2020) Blind trading: A literature review of research addressing the welfare of Ball pythons in the exotic pet trade. Animals, 10(2): 193.

48. Humane Society International. (2020) Wildlife Markets and COVID-19. HSA, Washington, DC. Available from: https://www.hsi.org/wp-content/uploads/2020/04/ Wildlife-Markets-and-COVID-19-White-Paper-FINAL-6Apr-2020.pdf. Retrieved on 02-06-2020.

49. Auliya, M. (2003) Hot Trade in Cool Creatures: A Review of the Live Reptile Trade in the European Union in the 1990s with a Focus on Germany. TRAFFIC Europe, Brussels, Belgium.

50. Reperant, L., Brown, I., Haenen, O., De Jong, M., Osterhaus, A.D., Papa, A., Rimstad, E., Valarcher, J.F. and Kuiken, T. (2016) Companion animals as a source of viruses for human beings and food production animals. $J$. Comp. Pathol., 155(1): S41-S53.

51. Kvapil, P., Kastelic, M., Dovč, A., Bártová, E., Č́žžek, P., Lima, N. and Štrus, Š. (2017) An eight-year survey of the intestinal parasites of carnivores, hoofed mammals, primates, ratites and reptiles in the Ljubljana zoo in Slovenia. Folia Parasitol., 64: 13

52. Karesh, W., Smith, K. and Asmüssen, M. (2012) The unregulated and informal trade in wildlife: Implications for biodiversity and health. In: Animal health and Biodiversity: Preparing for the Future. Compendium of the OIE Global Conference on Wildlife, Paris, France, 23-25 February 2011. p51-57.

53. Austin, B. (2010) Vibrios as causal agents of zoonoses. Vet. Microbiol., 140(3-4): 310-317.

54. Tischer, B.K. and Osterrieder, N. (2010) Herpesviruses a zoonotic threat? Vet. Microbiol., 140(3-4): 266-270.

55. Macpherson, C.N. (2013) The epidemiology and public health importance of toxocariasis: A zoonosis of global importance. Int. J. Parasitol., 43(12-13): 999-1008.

56. Spickler, A.R. (2015) Pathogens and Host Species in Zoonoses. Merk Sharp and Dohme Veterinary Manual. Available from: https://www.msdvetmanual.com/public-health/zoonoses/pathogens-and-host-species-in-zoonoses. Retrieved on 02-06-2020. 
57. Gaggelli, E., Jankowska, E., Kozlowski, H., Marcinkowska, A., Migliorini, C., Stanczak, P., Valensin, D. and Valensin, G. (2008) Structural characterization of the intra-and inter-repeat copper binding modes within the $\mathrm{N}$-terminal region of "prion related protein"(PrP-rel-2) of zebrafish. J. Phys. Chem. B, 112(47): 15140-15150.

58. Ariel, E. (2011) Viruses in reptiles. BMC Vet. Res., 42(1): 100.

59. Marschang, R.E. (2011) Viruses infecting reptiles. Viruses, 3(11): 2087-2126.

60. Bean, A.G., Baker, M.L., Stewart, C.R., Cowled, C., Deffrasnes, C., Wang, L.F. and Lowenthal, J.W. (2013) Studying immunity to zoonotic diseases in the natural host keeping it real. Nat. Rev. Immunol., 13(12): 851-861.

61. Centers for Disease Control and Prevention. (2020) Ebola Virus. Centers for Disease Control and Prevention. Centers for Disease Control and Prevention, Atlanta, Georgia, United States. Available from: https://www.avma.org/ebola-virus. Retrieved on 13-05-2020.

62. World Health Organization. (2014) Ebola Virus Disease and Household Pets. World Health Organization, Geneva. Available from: https://www.who.int/csr/resources/publications/ebola/household-pets/en. Retrieved on 13-05-2020.

63. Rewar, S. and Mirdha, D. (2014) Transmission of Ebola virus disease: An overview. Ann. Glob. Health, 80(6); 444-451.

64. Centers for Disease Control and Prevention. (2020) 1918 Pandemic (H1N1 virus). Centers for Disease Control and Prevention, Atlanta, Georgia. Available from: https://www. cdc.gov/flu/pandemic-resources/1918-pandemic-h1n1. $\mathrm{html}$. Retrieved on 22-05-2020.

65. Centers for Disease Control and Prevention. (2020) 19571958 Pandemic (H2N2 virus). Centers for Disease Control and Prevention, Atlanta, Georgia. Available from: https:// www.cdc.gov/flu/pandemic-resources/1957-1958-pandemic.html. Retrieved on 22-05-2020.

66. Jackson, C. (2009) History lessons: The Asian Flu pandemic. Br. J. Gen. Pract., 59(565): 622-623.

67. Centers for Disease Control and Prevention. (2020) 1968 Pandemic (H3N2 virus). Centers for Disease Control and Prevention, Atlanta, Georgia. Available from: https:/www. cdc.gov/flu/pandemic-resources/1968-pandemic.html. Retrieved on 22-05-2020.

68. Leroy, E.M., Kumulungui, B., Pourrut, X., Rouquet, P., Hassanin, A., Yaba, P., Délicat, A., Paweska, J.T., Gonzalez, J.P. and Swanepoel, R. (2005) Fruit bats as reservoirs of Ebola virus. Nature, 438(7068): 575-576.

69. Rouquet, P., Froment, J.M., Bermejo, M., Kilbourn, A., Karesh, W., Reed, P., Kumulungui, B., Yaba, P., Délicat, A. and Rollin, P.E. (2005) Wild animal mortality monitoring and human Ebola outbreaks, Gabon and Republic of Congo, 2001-2003. Emerg. Infect. Dis., 11(2): 283.

70. Sharp, P. and Hahn, B.H. (2011) Origins of HIV and the AIDS pandemic. Cold Spring Harb. Perspect. Med., 1(1): a006841.

71. Centers for Disease Control and Prevention. (1997) Human Monkeypox -- Kasai Oriental, Zaire, 1996-1997. Centers for Disease Control and Prevention, Atlanta, Georgia. Available from: https://www.cdc.gov/mmwr/preview/ mmwrhtml/00048673.htm. Retrieved on 22-05-2020.

72. Maskalyk, J. (2003) Monkeypox outbreak among pet owners. CMAJ, 169(1): 44-45.

73. Centers for Disease Control and Prevention. (1997) Isolation of Avian Influenza A(H5N1) Viruses from Humans--Hong Kong, May-December 1997. Centers for Disease Control and Prevention, Atlanta, Georgia. Available from: https:// www.cdc.gov/mmwr/preview/mmwrhtml/00050459.htm. Retrieved on 22-05-2020.

74. Hranac, C.R., Marshall, J.C., Monadjem, A. and Hayman, D.T. (2019) Predicting Ebola virus disease risk and the role of African bat birthing. Epidemics, 29: 100366.

75. World Health Organization. (2003) Summary of Probable
SARS Cases with Onset of Illness from 1 November 2002 to 31 July 2003. World Health Organization, Geneva: Available from: https://www.who.int/csr/sars/country/ table2004_04_21/en. Retrieved on 20-05-2020.

76. Centers for Disease Control and Prevention. (2020) CDC SARS Response Timeline. Centers for Disease Control and Prevention, Atlanta, Georgia. Available from: https:// www.cdc.gov/about/history/sars/timeline.htm. Retrieved on 13-05-2020.

77. European Centre for Disease Prevention and Control. (2018) Monkeypox Cases in the UK Imported by Travellers Returning from Nigeria, 2018. European Centre for Disease Prevention and Control, Stockholm. Available from: https://www.ecdc.europa.eu/sites/portal/files/documents/13-09-2018-RRA-Monkeypox-Nigeria-United-Kingdom.pdf. Retrieved on 06-06-2020.

78. Centers for Disease Control and Prevention. (2018) 2003 United States Outbreak of Monkeypox. Centers for Disease Control and Prevention, Atlanta, Georgia. Available from: https://www.cdc.gov/poxvirus/monkeypox/outbreak.html. Retrieved on 22-05-2020.

79. World Health Organization. (2019) Monkeypox. World Health Organization, Geneva: Available from: https:// www.who.int/news-room/fact-sheets/detail/monkeypox. Retrieved on 22-05-2020.

80. World Health Organization. (2011) Cumulative Number of Confirmed Human Cases for Avian Influenza A(H5N1) Reported to WHO, 2003-2011. World Health Organization, Geneva. Available from: https://www. who.int/influenza/human animal interface/EN GIP_20110819CumulativeNumberH5N1 ${ }^{-}$casesN.pdf?ua $=\overline{1}$. Retrieved on 02-06-2020.

81. World Health Organization. (2014) H5N1 Highly Pathogenic Avian Influenza: Timeline of Major Events WHO. World Health Organization, Geneva. Available from: https://www.who.int/influenza/human_animal_interface/ h5n1_avian_influenza_update20140714.pdf. Retrieved on 02-0б-2020.

82. Leroy, E.M., Epelboin, A., Mondonge, V., Pourrut, X., Gonzalez, J.P., Muyembe-Tamfum, J.J. and Formenty, P. (2009) Human Ebola outbreak resulting from direct exposure to fruit bats in Luebo, Democratic Republic of Congo, 2007. Vector Borne Zoonotic Dis., 9(6): 723-728.

83. Gibbs, A.J., Armstrong, J.S. and Downie, J.C. (2009) From where did the 2009 "swine-origin" influenza A virus (H1N1) emerge? Virol. J., 6: 207.

84. Kelly, H., Peck, H.A., Laurie, K.L., Wu, P., Nishiura, H. and Cowling, B.J. (2011) The age-specific cumulative incidence of infection with pandemic influenza H1N1 2009 was similar in various countries prior to vaccination. PLoS One, 6(8): e21828.

85. World Health Organization. (2019) Middle East Respiratory Syndrome Coronavirus (MERS-CoV). World Health Organization, Geneva. Available from: https://www. who.int/news-room/fact-sheets/detail/middle-east-respiratory-syndrome-coronavirus-(mers-cov). Retrieved on 02-06-2020.

86. World Health Organization. (2019) Middle East Respiratory Syndrome Coronavirus (MERS-CoV). MERS Monthly Summary November 2019. World Health Organization, Geneva. Available from: https://www.who.int/emergencies/ mers-cov/en. Retrieved on 02-06-2020.

87. Breman, J.G., Heymann, D.L., Lloyd, G., McCormick, J.B., Miatudila, M., Murphy, F.A., Muyembé-Tamfun, J.J., Piot, P., Ruppol, J.F. and Sureau, P. (2016) Discovery and description of Ebola Zaire virus in 1976 and relevance to the West African epidemic during 2013-2016. J. Infect. Dis., 214(Suppl 3): S93-S101.

88. Lau, S.K., Luk, H.K., Wong, A.C., Li, K.S., Zhu, L., He, Z., Fung, J., Chan, T.T., Fung, K.S. and Woo, P.C. (2020) Possible bat origin of severe acute respiratory syndrome coronavirus 2. Emerg. Infect. Dis., 26(7): 1542. 
89. Xiao, K., Zhai, J., Feng, Y., Zhou, N., Zhang, X., Zou, J.J., Li, N., Guo, Y., Li, X. and Shen, X. (2020) Isolation of SARS-CoV-2-related coronavirus from Malayan pangolins. Nature, 583(7815): 286-289.

90. Bateson, P. (1991) Assessment of pain in animals. Anim. Behav., 42(5): 827-839.

91. Broom, D.M. (1986) Indicators of poor welfare. Br. Vet. J., 142(6): 524-526.

92. Broom, D.M. (1991) Animal welfare: Concepts and measurement. J. Anim. Sci., 69(10): 4167-4175.

93. Broom, D.M. (2007) Cognitive ability and sentience: Which aquatic animals should be protected? Dis. Aquat. Organ., 75(2): 99-108.

94. Broom, D.M. (2019) Sentience. In: Choe, J.C., editor. Encyclopedia of Animal Behavior. $2^{\text {nd }}$ ed. Academic Press, Oxford. p131-133.

95. Broom, D., Galindo, F. and Murgueitio, E. (2013) Sustainable, efficient livestock production with high biodiversity and good welfare for animals. Proc. R. Soc. B Biol. Sci., 280(1771): 20132025

96. Warwick, C., Frye, F.L. and Murphy, J.B. (1995) Introduction: Health and welfare of captive reptiles. In: Warwick, C., Frye, F.L. and Murphy, J.B. editors Health and Welfare of Captive Reptiles. Springer, Berlin, Germany. p1-4.

97. Webster, A.J.F. (1998) What use is science to animal welfare? Naturwissenschaften, 85(6): 262-269.

98. Moberg, G. and Mench, J. (2000) Biology of Animal Stress. Basic Principles and Implications for Animal Welfare. CABI, Wallingford, United Kingdom.

99. Clubb, R. and Mason, G. (2003) Captivity effects on wide-ranging carnivores. Nature, 425(6957): 473-474.

100. Mendl, M. (2001) Assessing the welfare state. Nature, 410(6824): 31-32

101. Menzel, R., Brembs, B. and Giurfa, M. (2007) Cognition in invertebrates. In: Kaas, J.H., editor. Evolution of Nervous Systems, Academic Press, Oxford,. Vol. 2.. p403-442.

102. Mellor, D.J. (2012) Animal emotions, behaviour and the promotion of positive welfare states. N. Z. Vet. J., 60(1): 1-8.

103. Mellor, D.J. (2015) Positive animal welfare states and reference standards for welfare assessment. N. Z. Vet. J., 63(1): 17-23.

104. Mellor, D.J. (2016) Updating animal welfare thinking: Moving beyond the "five freedoms" towards "a life worth living". Animals, 6(3): 21.

105. Mellor, D.J. (2017) Operational details of the five domains model and its key applications to the assessment and management of animal welfare. Animals, 7(8): 60.

106. Elwood, R.W. (2011) Pain and suffering in invertebrates? ILAR J., 52(2): 175-184.

107. Crook, R. (2013) The welfare of invertebrate animals in research: Can science's next generation improve their lot. Postdoct. J., 1(2): 1-20.

108. Martínez-Silvestre, A. (2014) How to assess stress in reptiles. J. Exot. Pet Med., 23(3): 240-243.

109. Mellor, D.J. and Beausoleil, N. (2015) Extending the "five domains" model for animal welfare assessment to incorporate positive welfare states. Anim. Welf., 24(3): 241.

110. Mendl, M., Mason, G. and Paul, E.S. (2017) Animal welfare science. In: Call, G.M.B., Pepperberg, I.M., Snowdon, C.T. and Zentall, T., editors. APA Handbook of Comparative Psychology. American Psychological Association, Washington, DC. p793-811.

111. Perry, C.J. and Baciadonna, L. (2017) Studying emotion in invertebrates: What has been done, what can be measured and what they can provide. J. Exp. Biol., 220(21): 3856-3868.

112. Abramson, C.I. and Wells, H. (2018) An inconvenient truth: Some neglected issues in invertebrate learning. Perspect. Behav. Sci., 41(2): 395-416.

113. Zhang, K. (2018) Environmental stressor, stress response, and disease. Environ. Dis., 3(1): 1-3.
114. Lambert, H., Carder, G. and D'Cruze, N. (2019) Given the cold shoulder: A review of the scientific literature for evidence of reptile sentience. Animals, 9(10): 821.

115. Tarazona, A.M., Ceballos, M.C. and Broom, D.M. (2020) Human relationships with domestic and other animals: One health, one welfare, one biology. Animals, 10(1): 43.

116. Learmonth, M.J. (2020) The matter of non-avian reptile sentience, and why it "matters" to them: A conceptual, ethical and scientific review. Animals, 10(5): 901.

117. Mancera, K., Murray, P., Gao, Y., Lisle, A. and Phillips, C. (2014) The effects of simulated transport on the behaviour of eastern blue tongued lizards (Tiliqua scincoides). Anim. Welf., 23(3): 239-249.

118. Mancera, K.F., Murray, P.J., Lisle, A., Dupont, C., Faucheux, F. and Phillips, C.J.C. (2017) The effects of acute exposure to mining machinery noise on the behaviour of eastern blue-tongued lizards (Tiliqua scincoides). Anim. Welf., 26(1): 11-24.

119. World Small Animal Veterinary. (2018) WSAVA Animal Welfare Guidelines for Companion Animal Practitioners and Veterinary Teams. World Small Animal Veterinary. Available from: https://www.wsava.org/wp-content/uploads/2019/12/ WSAVA-Animal-Welfare-Guidelines-2018.pdf. Retrieved on 02-06-2020.

120. World Animal Protection. (2020) World Health Organisation Must Urge Governments to Ban Wildlife Markets WAP. Available from: https:/www.worldanimalprotection.org. $\mathrm{uk} /$ news/world-health-organisation-must-urge-governments-ban-wildlife-markets. Retrieved on 19-06-2020.

121. Gross, T.L. (2003) Scientific and moral considerations for live market practices. J. Am. Vet. Med. Assoc., 222(3): 285-288.

122. Daly, N. (2020) More Chinese Push to end Wildlife Markets as Coronavirus Outbreak Grows. National Geographic. Available from: https://www.nationalgeographic.co.uk/ science-and-technology/2020/01/more-chinese-push-endwildlife-markets-coronavirus-outbreak-grows. Retrieved on 06-06-2020.

123. Anon. (2020) Call to WHO to Ban Wild Animal Markets to Save Lives. Available from: https://www. rcinet.ca/en/2020/04/08/ban-wildlife-wet-markets-pandemic-covid-world-animal-protection. Retrieved on 06-06-2020.

124. Bachand, N., Ravel, A., Onanga, R., Arsenault, J. and Gonzalez, J.P. (2012) Public health significance of zoonotic bacterial pathogens from bushmeat sold in urban markets of Gabon, Central Africa. J. Wildl. Dis., 48(3): 785-789.

125. Warwick, C. (1990) Reptiles: Misunderstood, Mistreated and Mass-marketed. Reptile Protection Trust, Worcester, $\mathrm{UK}, \mathrm{pp} 47$.

126. Close, B., Banister, K., Baumans, V., Bernoth, E.M., Bromage, N., Bunyan, J., Erhardt, W., Flecknell, P., Gregory, N., Hackbarth, H., Morton, D. and Warwick, C. (1997) Recommendations for euthanasia of experimental animals: Part 2. DGXT of the European Commission. Lab. Anim., 31(1): 1-32.

127. Close, B., Banister, K., Baumans, V., Bernoth, E.M., Bromagem, N., Bunyan, J., Erhardt, W., Flecknell, P., Gregory, N., Hackbarth, H., Morton, D. and Warwick, C. (1996) Recommendations for euthanasia of experimental animals: Part 1. DGXI of the European Commission. Lab. Anim., 30(4): 293-316.

128. American Veterinary Medical Association. (2020) AVMA Guidelines for the Euthanasia of Animals: 2020 Edition. American Veterinary Medical Association. Available from: https://www.avma.org/sites/default/files/2020-01/2020-Euthanasia-Final-1-17-20.pdf. Retrieved on 06-06-2020.

129. OIE World Organisation for Animal Health. (2019) Terrestrial Animal Health Code: Killing of Reptiles for Their Skin, Meat and Other Products. OIE World Organisation for Animal Health. Available from: http://www.oie.int/index. php?id $=169 \& \mathrm{~L}=0 \&$ htmfile $=$ chapitre_aw_reptiles.htm. 
Retrieved on 25-05-2020.

130. Cooper, J.E., Ewbank, R., Platt, C. and Warwick, C. (1989) Euthanasia of Amphibians and Reptiles, Universities Federation for Animal Welfare/World Society for the Protection of Animals, England. p35.

131. Brown, C. (2004) Emerging zoonoses and pathogens of public health significance--an overview. Rev. Sci. Tech., 23(2): 435-442.

132. Chomel, B.B., Belotto, A. and Meslin, F.X. (2007) Wildlife, exotic pets, and emerging zoonoses. Emerg. Infect. Dis., 13(1): 6-11.

133. Hasanov, E., Zeynalova, S., Geleishvili, M., Maes, E., Tongren, E., Marshall, E., Banyard, A., Mcelhinney, L., Whatmore, A. and Fooks, A. (2018) Assessing the impact of public education on a preventable zoonotic disease: Rabies. Epidemiol. Infect., 146(2): 227-235.

134. Mermin, J., Hutwagner, L., Vugia, D., Shallow, S., Daily, P., Bender, J., Koehler, J., Marcus, R., Angulo, F.J. and Emerging Infections Program FoodNet Working Group. (2004) Reptiles, amphibians, and human Salmonella infection: A population-based, case-control study. Clin. Infect. Dis., 38(Suppl 3): S253-S261.

135. Chandrasekar, P.H. (2016) Infections in the Immunosuppressed Patient: An Illustrated Case-based Approach. Oxford University Press, Oxford.

136. Asokan, G., Asokan, V. and Tharyan, P. (2011) One health national programme across species on zoonoses: A call to the developing world. Infect. Ecol. Epidemiol., 1(1): 8293.

137. Warwick, C. (2004) Gastrointestinal disorders: Are health care professionals missing zoonotic causes? J. R. Soc. Promot. Health, 124(3): 137-142.

138. Warwick, C. and Corning, S. (2013) Managing patients for zoonotic disease in hospitals. JRSM Open, 4(8): 2042533313490287.

139. Bosch, S., Tauxe, R.V. and Behravesh, C.B. (2016) Turtleassociated salmonellosis, United States, 2006-2014. Emerg. Infect. Dis., 22(7): 1149.

140. Ashley, S., Brown, S., Ledford, J., Martin, J., Nash, A.E., Terry, A., Tristan, T. and Warwick, C. (2014) Morbidity and mortality of invertebrates, amphibians, reptiles, and mammals at a major exotic companion animal wholesaler. $J$. Appl. Anim. Welf. Sci., 17(4): 308-321.

141. Warwick, C., Arena, P.C. and Steedman, C. (2013) Health implications associated with exposure to farmed and wild sea turtles. JRSM Open, 4(1): 8.

142. Mitchell, M. and Shane, S. (2000) Preliminary findings of Salmonella spp. in captive green iguanas (Iguana iguana) and their environment. Prev. Vet. Med., 45(3-4): 297-304.

143. Lee, K., McReynolds, J., Fuller, C., Jones, B., Herrman, T., Byrd, J. and Runyon, M. (2008) Investigation and characterization of the frozen feeder rodent industry in Texas following a multi-state Salmonella Typhimurium outbreak associated with frozen vacuum-packed rodents. Zoonoses Public Health, 55(8-10): 488-496.

144. Defra. (2011) Zoonoses Report. Available from: https:// www.assets.publishing.service.gov.uk/government/uploads/ system/uploads/attachment data/file/69313/pb13571-zoonoses2009-110125.pdf. Retrieved on 14.01.2021.

145. Zhang, Y., Chen, C., Zhu, S., Shu, C., Wang, D., Song, J., Song, Y., Zhen, W., Feng, Z. and Wu, G. (2020) Isolation of 2019-nCoV from a stool specimen of a laboratory-confirmed case of the coronavirus disease 2019 (COVID-19). China CDC Wkly., 2(8): 123-124.

146. Nadeem, M.S., Zamzami, M.A., Choudhry, H., Murtaza, B.N., Kazmi, I., Ahmad, H. and Shakoori, A.R. (2020) Origin, potential therapeutic targets and treatment for coronavirus disease (COVID-19). Pathogens, 9(4): 307.

147. Shi, J., Wen, Z., Zhong, G., Yang, H., Wang, C., Liu, R., He, X., Shuai, L., Sun, Z., Zhao, Y., Liang, L., Cui, P., Wang, J., Zhang, X., Guan, Y., Chen, H. and Bu, Z. (2020) Susceptibility of ferrets, cats, dogs, and different domestic animals to SARS-coronavirus-2. Science, 368(6494):
1016-1020

148. Wacharapluesadee, S., Olival, K.J., Kanchanasaka, B., Duengkae, P., Kaewchot, S., Srongmongkol, P., Ieamsaard, G., Maneeorn, P., Sittidetboripat, N. and Kaewpom, T. (2015) Surveillance for Ebola virus in wildlife, Thailand. Emerg. Infect. Dis., 21(12): 2271

149. Warwick, C. (2006) Zoonoses: Drawing the Battle Lines. Vet. Times, 36: 26-28. Available from: https://www.emergentdisease.org/assets/documents/vt 2006 zoonoses_copy. pdf. Retrieved on 15-01-2021.

150. Pfeffer, M. and Dobler, G. (2010) Emergence of zoonotic arboviruses by animal trade and migration. Parasit. Vectors, 3(1): 35 .

151. OIE World Organisation for Animal Health. (2020) Newcastle Disease. OIE World Organisation for Animal Health. Available from: https://www.oie.int/en/animalhealth-in-the-world/animal-diseases/newcastle-disease. Retrieved on 28-05-2020.

152. OIE World Organisation for Animal Health. (2020) Heartwater-Cowdriosis. OIE. OIE World Organisation for Animal Health. Available from: https://www.oie.int/fileadmin/Home/eng/Animal_Health_in the_World/docs/pdf/ Disease_cards/HEARTWATER_FINĀL.pdf. Retrieved on $28-05-2020$.

153. Spickler, A.R. (2015) Heartwater. The Center for Food Safety and Public Health. Available from: http://www. cfsph.iastate.edu/Factsheets/pdfs/heartwater.pdf. Retrieved on 28-05-2020.

154. Clarke, T. (2001) Passports for Pet Tortoises. Nature Publishing Group, Berlin, Germany.

155. Centers for Disease Control and Prevention. (2018) Highly Pathogenic Asian Avian Influenza A(H5N1) Virus CDC. Available from: https://www.cdc.gov/flu/avianflu/h5n1-virus.htm. Retrieved on 28-05-2020.

156. OIE World Organisation for Animal Health. (2020) Avian Influenza Portal. OIE. OIE World Organisation for Animal Health. Available from: https://www.oie.int/en/ animal-health-in-the-world/avian-influenza-portal/prevention-and-control. Retrieved on 28-05-2020.

157. Dudley, J.P. (2006) Bird flu outbreak in United Kingdom reveals global vulnerabilities. Bioscience, 56(3): 182-183.

158. The Netherlands Ministry of Agriculture Nature and Food Quality. (2020) Update SARS-CoV-2 in Mink in The Netherlands. Available from: https://www.oie.int/filead$\mathrm{min} /$ Home/eng/Our_scientific_expertise/docs/pdf/COV-19/ Bruschke_update_SARS_CoV_3_infections_in_mink_ Netherlands 9June2020.pdf. Retrieved on 28-06-2020.

159. Miller, R. (1996) Quarantine protocols and preventive medicine procedures for reptiles, birds and mammals in zoos. Rev. Sci. Tech., 15(1): 183-188.

160. Resanovic, R. (2002) Quarantine for imported exotic birds. Zivinarstvo, 37(6/7): 145-146.

161. Cooper, J.E. and Williams, D.L. (1995) Veterinary perspectives and techniques in husbandry and research. In: Warwick, C., Frye, F.L. and Murphy, J.B., editors. Health and Welfare of Captive Reptiles. Springer, Berlin, Germany. p98-112.

162. Davis, A.D., Dupuis, M. and Rudd, R.J. (2012) Extended incubation period of rabies virus in a captive big brown bat (Eptesicus fuscus). J. Wildl. Dis., 48(2): 508-511.

163. Jackson, B., Harvey, C., Galbraith, J., Robertson, M., Warren, K., Holyoake, C., Julian, L. and Varsani, A. (2014) Clinical beak and feather disease virus infection in wild juvenile Eastern Rosellas of New Zealand; biosecurity implications for wildlife care facilities. N. Z. Vet. J., 62(5): 297-301.

164. Boinas, F.S., Wilson, A.J., Hutchings, G.H., Martins, C. and Dixon, L.J. (2011) The persistence of African swine fever virus in field-infected Ornithodoros erraticus during the ASF endemic period in Portugal. PLoS One, 6(5): e20383.

165. United States Government Accountability Office. (2010) Report to the Committee on Homeland Security and 
Governmental Affairs, U.S. Senate. Live Animal Imports: Agencies Need Better Collaboration to Reduce the Risk of Animal-Related Diseases. United States Government Accountability Office, United States.

166. Scheffers, B.R., Oliveira, B.F., Lamb, I. and Edwards, D.P. (2019) Global wildlife trade across the tree of life. Science, 366(6461): 71-76.

167. World Wildlife Fund. (2020) Second-biggest Direct Threat to Species after Habitat Destruction WWF. Available from: https:/www.f.panda.org/our_work/wildlife/problems/illegal_trade. Retrieved on 28-05-2020.

168. TRAFFIC. (2020) Illegal Wildlife Trade: Enhancing Responses to Wildlife Crime and Illegal Trade Traffic. Available from: https://www.traffic.org/about-us/illegal-wildlife-trade. Retrieved on 02-06-2020.

169. Warwick, C., Steedman, C., Jessop, M., Arena, P., Pilny, A. and Nicholas, E. (2018) Exotic pet suitability: Understanding some problems and using a labeling system to aid animal welfare, environment, and consumer protection. J. Vet. Behv., 26: 17-26.

170. Harfoot, M., Glaser, S.A., Tittensor, D.P., Britten, G.L., McLardy, C., Malsch, K. and Burgess, N.D. (2018) Unveiling the patterns and trends in 40 years of global trade in CITES-listed wildlife. Biol. Conserv., 223: 47-57.

171. Nijman, V. (2010) An overview of international wildlife trade from Southeast Asia. Biodivers. Conserv., 19(4): 1101-1114.

172. Hartl, B. (2020) Plan: Preventing Future Pandemics Requires Sweeping U.S. Action on Wildlife Trade. Available from: https://www.biologicaldiversity.org/w/news/press-releases/plan-preventing-future-pandemics-requires-sweeping-us-action-wildlife-trade-2020-05-18. Retrieved on 28-05-2020.

173. Clayton, L. and Milner-Gulland, E. (2000) The trade in wildlife in North Sulawesi, Indonesia. In: Robinson, J. and Bennett, E., editors Hunting for Sustainability in Tropical Forests. Columbia University Press, New York. p473-496.

174. Round, P.D. (1990) Bangkok bird club survey of the bird and mammal trade in the Bangkok weekend market. Nat. Hist. Bull. Siam. Soc., 38: 1-43.

175. United Nations. (2020) Convention on International Trade in Endangered Species of Wild Fauna and Flora (CITES): A Contribution to the Global Follow-up and Review in the 2017 High Level Political Forum (HLPF) on the Work of the Convention on International Trade in Endangered Species of Wild Fauna and Flora. UN. Available from: https://www. sustainabledevelopment.un.org/index.php?page=view\&type $=30022 \& \mathrm{nr}=650 \&$ menu $=3170$. Retrieved on 02-06-2020.

176. Natusch, D.J. and Lyons, J.A. (2012) Exploited for pets: The harvest and trade of amphibians and reptiles from Indonesian New Guinea. Biodivers. Conserv., 21(11): 2899-2911.

177. Li, P. (2020) Covid-19 and the Prospect of Ending China's Wildlife Wet Marketing. Intergroup Presentation $23^{\text {rd }}$ April 2020.

178. Taormina, P.J. (2000) Produce as a potential source of bacterial infections in exotic pets. Compend. Contin. Educ. Vet., 22(7): 636-46.

179. Hoelzer, K., Switt, A.I.M. and Wiedmann, M. (2011) Animal contact as a source of human non-typhoidal salmonellosis. Vet. Res., 42(1): 34.

180. Martin, L., Andreassi, E., Watson, W. and Coon, C. (2011) Stress and animal health: Physiological mechanisms and ecological consequences. Nat. Educ. Knowl., 3(6): 11.

181. Wingfield, J.C. (2013) Ecological processes and the ecology of stress: The impacts of abiotic environmental factors. Funct. Ecol., 27(1): 37-44.

182. Takahashi, A., Flanigan, M.E., McEwen, B.S. and Russo, S.J. (2018) Aggression, social stress, and the immune system in humans and animal models. Front. Behav. Neurosci., 12: 56.

183. Christian, L.M. and Glaser, R. (2012) The impact of everyday stressors on the immune system and health. In: Stress Challenges and Immunity in Space. Springer, Berlin, Germany. p31-43.

184. Smith, K.M., Anthony, S.J., Switzer, W.M., Epstein, J.H., Seimon, T., Jia, H., Sanchez, M.D., Huynh, T.T., Galland, G.G., Shapiro, S.E., Sleeman, J.M., McAloose, D., Stuchin, M., Amato, G., Kolokotronis, S.O., Lipkin, W.I., Karesh, W.B., Daszak, P. and Marano, N. (2012) Zoonotic viruses associated with illegally imported wildlife products. PLoS One, 7(1): e29505.

185. Harris, M. (2020) A Warning From a Scientist Who Saw the Coronavirus Coming. Slate Group. Available from: https://www.slate.com/technology/2020/03/coronavirus-covid19-pandemic-cause-prediction-prevention.html. Retrieved on 06-06-2020.

186. TRAFFIC. (2012) Captive Bred or Wild Taken? Traffic International. Available from: https://www.traffic.org/site/ assets/files/7446/captive-bred-or-wild-taken.pdf. Retrieved on 28-05-2020.

187. Carroll, D., Watson, B., Togami, E., Daszak, P., Mazet, J.A., Chrisman, C.J., Rubin, E.M., Wolfe, N., Morel, C.M. and Gao, G.F. (2018) Building a global atlas of zoonotic viruses. Bull. World Health Organ., 96(4): 292.

188. Global Virome Project. (2020) The Global Virome Project (GVP) is a 10-year Collaborative Scientific Initiative to Discover Unknown Zoonotic Viral Threats and Stop Future Pandemics. Available from: http://www.globalviromeproject.org. Retrieved on 06-06-2020.

189. Casadevall, A., Konopka, J.B., Taylor, J.W., Heitman, J. and Cowen, L. (2019) One health: Fungal Pathogens of Humans, Animals, and Plants. Report on an American Academy of Microbiology Colloquium held in Washington, DC, on October 18, 2017. American Society for Microbiology, Washington, DC.

190. Dolejska, M. and Literak, I. (2019) Wildlife is overlooked in the epidemiology of medically important antibiotic-resistant bacteria. Antimicrob. Agents Chemother., 63(8): e01167-01119.

191. Weinstein, R.A., Weber, D.J. and Rutala, W.A. (2001) Risks and prevention of nosocomial transmission of rare zoonotic diseases. Clin. Infect. Dis., 32(3): 446-456.

192. Kaplan, B. (2011) One Health or some health. Vet. Ital., 47(2): 129-131.

193. Yamada, A., Kahn, L.H., Kaplan, B., Monath, T.P., Woodall, J. and Conti, L. (2014) Confronting Emerging Zoonoses: The One Health Paradigm. Springer, Berlin, Germany.

194. Eskew, E.A., White, A.M., Ross, N., Smith, K.M., Smith, K.F., Rodríguez, J.P., Zambrana-Torrelio, C., Karesh, W.B. and Daszak, P. (2020) United States wildlife and wildlife product imports from 2000-2014. Sci. Data, 7(1): $1-8$.

195. Wang, L. and Crameri, G. (2014) Emerging zoonotic viral diseases. Rev. Sci. Tech., 33(2): 569-581.

196. Ceballos, G., Ehrlich, P.R. and Raven, P.H. (2020) Vertebrates on the brink as indicators of biological annihilation and the sixth mass extinction. Proc. Natl. Acad. Sci., 117(24): 13596-13602.

197. Eurogroup for Animals. (2020) Open Letter to the WHO about COVID-19 Health Risks and Wildlife Markets. Available from: https://www.eurogroupforanimals.org/ news/open-letter-who-about-covid-19-health-risks-andwildlife-markets. Retrieved on 19-06-2020.

198. Lieberman, S. (2020) CITES, the Treaty that Regulates Trade in International Wildlife, is not the Answer to Preventing Another Zoonotic Pandemic. Scientific American. Available from: https://www.blogs.scientificamerican.com/observations/cites-the-treaty-that-regulates-trade-in-internationalwildlife-is-not-the-answer-to-preventing-another-zoonoticpandemic. Retrieved on 02-06-2020.

199. Greenfield, P. (2020) Ban Wildlife Markets to Avert Pandemics, Says UN Biodiversity Chief. The Guardian. 
Available from: https://www.theguardian.com/world/2020/ apr/06/ban-live-animal-markets-pandemics-un-biodiversity-chief-age-of-extinction. Retrieved on 14-01-2021.

200. World Wildlife Fund. (2020) Why we Must Close Highrisk Wildlife Markets WWF. Available from: https://www. worldwildlife.org/stories/why-we-must-close-high-riskwildlife-markets. Retrieved on 02-06-2020.

201. EndPandemics.earth. (2020) A Global Alliance. Available from: https://www.endpandemics.earth/about.html. Retrieved on 20-06-2020.

202. Challender, D., Hinsley, A., Verissimo, D. and t'SasRolfes, M. (2020) Coronavirus: Why a Blanket Ban on Wildlife Trade would not be the Right Response The Conversation. Available from: https://www.theconversation.com/coronavirus-why-a-blanket-ban-on-wildlifetrade-would-not-be-the-right-response-135746. Retrieved on 03-06-2020.

203. Eskew, E.A. and Carlson, C.J. (2020) Overselling wildlife trade bans will not bolster conservation or pandemic preparedness. Lancet Planet. Health, 4(6): e215-e216.

204. Santos, A., Satchabut, T. and Trauco, G.V. (2011) Do wildlife trade bans enhance or undermine conservation efforts. Appl. Biodivers. Perspect. Ser., 1(3): 1-15.

205. Toland, E., Warwick, C. and Arena, P. (2012) The exotic pet trade: Pet hate. Biologist, 59(3): 14-18.

206. Phelps, J., Biggs, D. and Webb, E.L. (2016) Tools and terms for understanding illegal wildlife trade. Front. Ecol. Environ., 14(9): 479-489.

207. Reino, L., Figueira, R., Beja, P., Araújo, M.B., Capinha, C. and Strubbe, D. (2017) Networks of global bird invasion altered by regional trade ban. Sci. $A d v$., 3(11): e1700783.

208. Wiersema, A. (2016) Incomplete bans and uncertain markets in wildlife trade. Univ. Pa. Asian Law Rev., 12(1): 65-87.

209. Cardador, L., Tella, J.L., Anadón, J.D., Abellán, P. and Carrete, M. (2019) The European trade ban on wild birds reduced invasion risks. Conserv. Lett., 12(3): e12631.

210. Stringham, O.C. and Lockwood, J.L. (2018) Pet problems: Biological and economic factors that influence the release of alien reptiles and amphibians by pet owners. J. Appl. Ecol., 55(6): 2632-2640.

211. Blumstein, D.T. (2013) Why we really don't care about the evidence in evidence-based decision making in conservation. In: Bekoff, M. editor. Ignoring Nature no More: The Case for Compassionate Conservation. The University of Chicago Press, Chicago and London, p103.

212. McCullock, S.P. (2020) A Wolf in Sheep's Clothing. The Ecologist, The Ecologist. Available from: https:// www.theecologist.org/2020/feb/11/wolf-sheeps-clothing. Retrieved on 02-06-2020.

213. Warwick, C. and Steedman, C. (in press) Exotic Pet Trading and Keeping: Proposing a Model Government Consultation and Advisory Protocol.

214. Toland, E., Bando, M., Hamers, M., Cadenas, V., Laidlaw, R., Martínez-Silvestre, A. and van der Wielen, P. (2020) Turning negatives into positives for pet trading and keeping: A review of positive lists.Animals, 10(12): 2371.

215. Pooley, S., Fa, J.E. and Nasi, R. (2015) No conservation silver lining to Ebola. Conserv. Biol., 29(3): 965-967.

216. Laidlaw, R. (2005) Scales and Tails: The Welfare and Trade of Reptiles Kept as Pets in Canada. Available from: https:// www.zoocheck.com/wp-content/uploads/2016/06/Reptile_ Report_FA.pdf. Retrieved on 02-06-2020.

217. Grant, $\bar{R}$. A., Montrose, V.T. and Wills, A.P. (2017) ExNOTic:
Should we be keeping exotic pets? Animals, 7(6): 47.

218. Jones, K.E., Patel, N.G., Levy, M.A., Storeygard, A., Balk, D., Gittleman, J.L. and Daszak, P. (2008) Global trends in emerging infectious diseases. Nature, 451(7181): 990-993.

219. Brugere-Picoux, J. and Chomel, B. (2009) Importation of infectious diseases to Europe via animals and animal products: Risks and pathways. Bull. Acad. Natl. Med. Paris, 193(8): 1805-1818; discussion 1819.

220. Praud, A. and Moutou, F. (2010) Health Risks from New Companion Animals. Commissioned by Eurogroup for Animals, Belgium.

221. Abbott, S.L., Ni, F.C. and Janda, J.M. (2012) Increase in extraintestinal infections caused by Salmonella enterica subspecies II-IV. Emerg. Infect. Dis., 18(4): 637-639.

222. Akhtar, A. (2012) Animals and Public Health: Why Treating Animals better is Critical to Human Welfare. Springer, Berlin, Germany.

223. Hale, C.R., Scallan, E., Cronquist, A.B., Dunn, J., Smith, K., Robinson, T., Lathrop, S., Tobin-D'Angelo, M. and Clogher, P. (2012) Estimates of enteric illness attributable to contact with animals and their environments in the United States. Clin. Infect. Dis., 54(Suppl 5): S472-S479.

224. Grayzel, S.E., Bender, J.B., Glore, R.P., Gumley, N., Sykes, J.E., Whichard, J.M., Papich, M.G., Watts, J.L., Barlam, T.F. and Murphy, M.J. (2015) Understanding companion animal practitioners' attitudes toward antimicrobial stewardship. J. Am. Vet. Med. Assoc., 247(8): 883-884.

225. Martin, M.J., Thottathil, S.E. and Newman, T.B. (2015) Antibiotics Overuse in Animal Agriculture: A Call to Action for Health Care Providers. American Public Health Association, Washington, DC.

226. Leite-Martins, L., Mahú, M., Costa, A., Bessa, L., VazPires, P., Loureiro, L., Niza-Ribeiro, J., de Matos, A. and da Costa, P.M. (2015) Prevalence of antimicrobial resistance in faecal enterococci from vet-visiting pets and assessment of risk factors. Vet. Rec., 176(26): 674.

227. Vilà, M., Basnou, C., Pyšek, P., Josefsson, M., Genovesi, P., Gollasch, S., Nentwig, W., Olenin, S., Roques, A. and Roy, D. (2010) How well do we understand the impacts of alien species on ecosystem services? A pan-European, cross-taxa assessment. Front. Ecol. Environ., 8(3): 135-144.

228. Henderson, W. and Bomford, M. (2011) Detecting and Preventing New Incursions of Exotic Animals in Australia, Invasive Animals Cooperative Research Centre Canberra, ACT, Australia.

229. Keller, R.P., Geist, J., Jeschke, J.M. and Kühn, I. (2011) Invasive species in Europe: Ecology, status, and policy. Environ. Sci. Eur., 23(1): 23.

230. Langton, T., Atkins, W. and Herbert, C. (2011) On the distribution, ecology and management of non-native reptiles and amphibians in the London Area. Part 1. Distribution and predator/prey impacts. London Nat., 90: 83-156.

231. Böhm, M., Collen, B., Baillie, J.E., Bowles, P., Chanson, J., Cox, N., Hammerson, G., Hoffmann, M., Livingstone, S.R. and Ram, M. (2013) The conservation status of the world's reptiles. Biol. Conserv., 157: 372-385.

232. Kopecký, O., Patoka, J. and Kalous, L. (2016) Establishment risk and potential invasiveness of the selected exotic amphibians from pet trade in the European Union. J. Nat. Conserv., 31: 22-28.

233. Kubiak, M. and Pellett, S. (2018) Invasive alien species legislation: A veterinary perspective. Companion Anim., 23(1): 44-48. 